\title{
Stock liquidity and default risk ${ }^{\text {负 }}$
}

\author{
Jonathan Brogaarda,*, Dan Li ${ }^{\mathrm{b}}$, Ying Xia ${ }^{\mathrm{c}}$ \\ ${ }^{a}$ Foster School of Business, University of Washington, Seattle, WA 98195, United States \\ ${ }^{b}$ School of Economics and Finance, Faculty of Business and Economics, The University of Hong \\ Kong, Pokfulam Road, Hong Kong \\ c Department of Banking and Finance, Monash Business School, Monash University, 900 \\ Dandenong Road, Caulfield East, VIC 3145, Australia
}

\begin{abstract}
This paper examines the impact of stock liquidity on firm bankruptcy risk. Using the Securities and Exchange Commission decimalization regulation as a shock to stock liquidity, we establish that enhanced liquidity decreases default risk. Stocks with the highest default risk experience the largest improvements. We find two mechanisms through which stock liquidity reduces firm default risk: improving stock price informational efficiency and facilitating corporate governance by blockholders. Of the two mechanisms, the informational efficiency channel has higher explanatory power than the corporate governance channel.
\end{abstract}

(for internet appendix click: http://bit.ly/2kdC3U9)

JEL classifications: G12; G14; G33; G34

Keywords: Stock liquidity; Bankruptcy risk; EDF; Price efficiency; Governance

We are grateful for helpful comments from Christophe Spaenjers and participants at the 2014 European Finance Association conference, the 2014 Financial Management Association conference, the 27th Australasian Finance and Banking conference, the 2015 International Finance and Banking Society conference, the 2015 European Financial Management Association conference, and seminar participants at the University of Manitoba and the University of Waterloo.

* Corresponding author. Tel.: +1 206685 7822; fax: +1 2065437472.

E-mail address: brogaard@uw.edu. 


\section{Introduction}

Default is among the most disruptive events in the life of a corporation. It adversely affects productivity through supply chain interruptions and employee attrition, incurs legal and administrative costs, and harms customer retention. Default occurs when a firm's cash flows are insufficient to cover its debt service costs and principal payments. Default risk increases when a firm's average cash flow level shifts down or its cash flow volatility increases, or both. A liquid market provides investors with the ability to trade stocks quickly and at minimal cost. Can liquidity help predict the likelihood of default? Can liquidity affect the risk of default? This paper studies the effect of stock liquidity on default risk.

Stock liquidity can impact default risk for a number of reasons. Increasing liquidity can increase default risk if it exacerbates noise trading, leading to greater firm mispricing and higher volatility (Baker, Stein, and Wurgler, 2003; Goldstein and Guembel, 2008; Ozdenoren and Yuan, 2008; Polk and Sapienza, 2009). Greater liquidity can also decrease internal firm monitoring (Bhide, 1993). Alternatively, higher liquidity could decrease default risk by improving price efficiency or improving corporate governance through easing investors' ability to exit. Fang, Noe, and Tice (2009) provide empirical evidence that liquidity increases firm value. Even so, the effect of stock liquidity on default risk is not mechanical as default risk can be nonlinear and it depends on several factors other than firm value.

Understanding the general empirical relation between liquidity and default risk is valuable. Liquidity as a predictor variable can help improve models measuring a firm's default risk. Having a real-time publicly observable signal to improve default risk models can lead to better contracting and risk management by suppliers, customers, and counterparties.

To capture default risk, we use the Bharath and Shumway (2008) measure of expected default frequency $(E D F)$. The $E D F$ is a simplified version of the Merton (1974) structural 
distance-to-default model. Researchers could examine bankruptcy events directly, but, as bankruptcies are rare, estimation techniques are difficult to implement in practice. Instead, models of default likelihood give cross-sectional and time-varying probabilities of default. Bharath and Shumway (2008) show that $E D F$ does surprisingly well at forecasting bankruptcies out of sample. The measure uses the same inputs as Merton's distance-to-default model and keeps the same functional form, but it forgoes the iterative solution procedure.

With $E D F$ as our measure of default risk, we evaluate the US equity market between 1994 and 2014. ${ }^{1}$ Overall, a negative relation exists between default risk and liquidity. A one standard deviation increase in liquidity measured by relative effective spread (Effective Spread) is associated with a drop of $26.89 \%$ over the sample mean of $E D F$.

While we are interested in whether liquidity affects default risk, default risk also could affect liquidity. For instance, bid-ask spreads can widen as a firm approaches default and its stock becomes more volatile. To overcome reverse causality concerns, we implement a difference-indifferences (DID) analysis around the 2001 decimalization event. In 2001, the Securities and Exchange Commission (SEC) reduced the minimum tick size from a sixteenth of a dollar to a hundredth of a dollar. Prior studies show that decimalization improves market liquidity significantly, especially among actively traded stocks (Goldstein and Kavajecz, 2000; Bessembinder, 2003).

The effect is large, with $E D F$ decreasing by $6.2 \%$ for the treatment group around decimalization. Separating stocks into quintiles based on pre-decimalization EDF shows that it is stocks with the highest default risk that are most affected. The riskiest quantile experiences a decline in $E D F$ of $14.64 \%$.

We rule out that the effect is mechanical. The event study shows that higher stock liquidity decreases default risk. We show that the effect is not mechanical via increased firm value as a

\footnotetext{
${ }^{1}$ The sample starts in 1994 because two of the liquidity measures are computed using Trade and Quote (TAQ) data, which starts at 1993, and we lag the liquidity measure for one year in the regression analysis.
} 
result of higher liquidity. The liquidity effect is more pronounced among firms experiencing a drop in firm value. The impact of an exogenous shock to liquidity on $E D F$ is largest for firms in which $\operatorname{Ln}$ (Equity) falls or $\operatorname{Ln}($ Debt) increases.

Finally, we study two channels that could be driving the relation between liquidity and default risk: information efficiency and governance. The first channel, higher information efficiency, can improve firm performance. Higher liquidity permits informed investors to profit more from their private information, thus incentivizing investors to acquire more information and trade on it, leading to more informed stock prices (Holden and Subrahmanyam, 1992; Holmström and Tirole, 1993; Subrahmanyam and Titman, 2001). Managers learn from stock prices and use it to guide corporate investments (Luo, 2005; Chen, Goldstein, and Jiang, 2007; Bakke and Whited, 2010). Consequently, managers make better investment decisions, generate higher cash flows, and reduce cash flow volatility, resulting in lower default risk. We return to examining the decimalization event. We perform the difference-in-differences analysis by subtracting the control group values from the treatment group, and we focus on the changes in price efficiency after decimalization. Price efficiency is captured using stock return correlation or the Hou and Moskowitz (2005) price delay measure. We find that stocks with the largest improvement in information efficiency experience the greatest reduction in default risk.

The second channel we explore is governance. Higher liquidity makes it easier for blockholders to sell stocks. Ex ante, the threat of exit can serve as an effective corporate governance mechanism (Admati and Pfleiderer, 2009; Edmans, 2009; Edmans and Manso, 2011). Good corporate governance disciplines managers. It urges them to engage in valueenhancing investments and guards against opportunistic management behavior, potentially leading to lower default probability. Using the same methodology as was used to investigate information efficiency, we empirically examine the corporate governance mechanism. We capture corporate governance by examining the number of shareholders holding greater than $5 \%$ 
of shares (blockholders) and using the fraction of shares held by these blockholders. Firms with a greater increase in governance monitoring have a larger decrease in default risk.

While the data show that the mechanisms driving the results include improving price efficiency and improving blockholder corporate governance, the price efficiency channel has higher explanatory power than the corporate governance channel. A one standard deviation improvement in price efficiency is associated with about an $11 \%$ increase in the standard deviation of the change of $E D F$.

This paper contributes to the growing literature showing that secondary markets have implications for firms; specifically, that liquidity can have real effects (Bond, Edmans, and Goldstein, 2012). We show that liquidity can influence default risk. Fang, Noe, and Tice (2009) show that stock liquidity improves firm value as measured by Tobin's q. Bharath, Jayaraman, and Nagar (2013) study the role of liquidity in blockholder's threat of exit and conclude that stock liquidity magnifies the effect of block ownership on firm value. Edmans, Fang, and Zur (2013) show that greater stock liquidity results in governance shifting from blockholder's voice to the threat of exit. Fang, Tian, and Tice (2014) find that an increase in liquidity leads to a decrease in firm innovation. Norli, Ostergaard, and Schindele (2015) show that greater stock liquidity can increase shareholder activism.

The remainder of this paper is organized as follows. Section 2 describes the data and variable construction. Section 3 presents the general empirical results. Section 4 evaluates causality. Section 5 examines the possible mechanisms. Section 6 concludes.

\section{Data and variable construction}

The sample construction starts with a comprehensive list of US common stocks between 1993 and 2013, which appears in both the Compustat Industrial files and the Center for Research in 
Security Prices (CRSP) stock file. ${ }^{2}$ We obtain intraday trades and quotes from the Trade and Quote (TAQ) database to construct the high-frequency liquidity measure. We exclude from our sample financial firms [standard industrial classification (SIC) codes between 6000 and 6999] because their accounting numbers are subject to statutory capital requirements. To ensure there are enough data points to compute liquidity measures, we exclude firm-year observations with lower than two hundred active trading days in a year. The accounting data are obtained from the CRSP and Compustat merged quarterly database. If the accounting information is missing for one year, the previous non-missing observation is used. The final sample contains 7,128 firms and 51,527 firm-year observations. All variable definitions are in Table 1.

We capture stock liquidity using both high-frequency and low-frequency measures. We consider two spread measures calculated using data from the TAQ database. Compared with variables based on daily data, high-frequency measures provide a better and more precise measure of trading cost (Goyenko, Holden, and Trzcinka, 2009). Our main liquidity measure is relative effective spread (Effective Spread), which captures the cost of a round-trip trade. The relative effective spread is defined as twice the difference between the execution price and the midpoint of the prevailing best quotes divided by the midpoint of the prevailing best bid-ask quote. We multiply the value by one hundred so the variable is in percentages.

We apply several filters to the TAQ data before computing the effective spread measures. We follow Hasbrouck (2010) to derive the National Best Bid and Offer (NBBO) and then match each trade to a prevailing national best bid-ask quote. ${ }^{3}$ Following Chordia, Roll, and Subrahmanyam (2001), we exclude records for which the bid-ask spread is larger than $\$ 5$, the dollar effective spread is more than four times larger than the dollar quoted spread, the relative effective spread

${ }^{2}$ The sample begins in 1993 as this is when the TAQ database begins. The sample period for EDF is from 1994 to 2014.

3 The SAS program suggested by Hasbrouck (2010) can be found on the Wharton Research Data Service website (https://wrds-web.wharton.upenn.edu/wrds/). Following Lee and Ready (1991), each trade from 1993 through 1998 is matched to the first quote that is at least five seconds prior to that trade. After 1998, the matching quote is the first quote prior to the trade. 
is four times larger than the relative quoted spread, and the bid-ask spread is more than $40 \%$ of the trade price. We classify trades into buyer-initiated and seller-initiated using the Lee and Ready (1991) algorithm.

The daily relative effective spread is the equal-weighted average of all intraday effective spread records. We then average across all trading days in a year to compute Effective Spread. A high spread implies low liquidity.

The second liquidity measure is percentage quoted spread (Quoted Spread), defined as the difference between the national best ask and bid price divided by the midpoint of the best bid and ask price. The value is multiplied by one hundred so the variable is in percentages. We first compute the daily equal-weighted average of all intraday relative quoted spread and then average across all trading days in a year to obtain Quoted Spread.

Our first low-frequency measure is the Amihud (2002) illiquidity ratio, Amihud, defined as the absolute value of daily stock return divided by daily dollar trading volume, multiplied by one million. The measure captures the idea that, for a given amount of trading, illiquid stocks should experience a larger change in price. A higher Amihud value corresponds to lower liquidity. Following Lesmond, Ogden, and Trzcinka (1999), the measure Zeros is defined as the proportion of days with zero returns, multiplied by one hundred. Illiquid stocks are more likely to experience trading days with zero returns due to either no trading interest or high trading cost. A higher Zeros value represents lower liquidity.

We construct a measure of expected default frequency as in Bharath and Shumway (2008), which is a simplified version of the Merton (1974) structural distance-to-default model. Merton (1974) considers a firm's equity a call option on the underlying value of the firm's assets with a strike price equal to the face value of the firm's debt, and a firm defaults when its asset value falls below the face value of the firm's debt. The model calculates a distant-to-default $(D D)$ measure. The resulting $D D$ measure is then substituted into a cumulative standard normal 
distribution to compute the probability that the value of a firm's assets will be less than the face value of its debt.

While the Merton model has been widely used in academic studies and by practitioners (Kealhofer and Kurbat, 2001; Crosbie and Bohn, 2003; Vassalou and Xing, 2004; Duffie, Saita, and Wang, 2007), Bharath and Shumway (2008) argue that the Merton model's predictive power mainly comes from its functional form, not the actual default probability produced by the model. Campbell, Hilscher, and Szilagyi (2008) reach a similar conclusion. Bharath and Shumway (2008) further propose a naïve default probability measure that retains the Merton model's structural form and same basic inputs while simplifying the calculation. They show that the naïve measure performs well. We follow Bharath and Shumway (2008) to compute EDF as follows:

$D D_{i, t}=\frac{\log \left(\frac{\text { Equity }_{i, t}+\text { Debt }_{i, t}}{\text { Debt }_{i, t}}\right)+\left(r_{i, t-1}-\frac{\sigma_{V i, t}^{2}}{2}\right) \times T_{i, t}}{\sigma_{V i, t} \times \sqrt{T_{i, t}}}$

$\sigma_{V i, t}=\frac{\text { Equity }_{i, t}}{\text { Equity }_{i, t}+\text { Debt }_{i, t}} \times \sigma_{E i, t}+\frac{\text { Debt }_{i, t}}{\text { Equity }_{i, t}+\text { Debt }_{i, t}} \times\left(0.05+0.25 \times \sigma_{E i, t}\right)$

and

$E D F_{i, t}=N\left(-D D_{i, t}\right)$

where Equity $_{i, t}$ is the market value of equity (in millions of dollars) calculated as the product of the number of shares outstanding and stock price at the end of the year; Debt $t_{i, t}$ is the face value of debt computed as the sum of debt in current liabilities (Compustat quarterly data \#45) and one-half of long-term debt (Compustat quarterly data \#51) at the end of the year; $r_{i t-1}$, firm $i$ 's past annual return, is calculated from monthly stock returns over the previous year; $\sigma_{E i, t}$ is the stock return volatility for firm $i$ during year $t$ estimated using the monthly stock return from the previous year; $\sigma_{V i, t}$, calculated from $\sigma_{E i, t}$, is an approximation of the volatility of firm assets; and 
$T_{i, t}$ is set to one year. We construct $D D_{i, t}$ of all sample firms as of the last day of each year. $N($.$) is$ the cumulative standard normal distribution function.

We use the same control variables as in Bharath and Shumway (2008). Ln(Equity) is the natural log of market value of equity at the end of the year. $\operatorname{Ln}(D e b t)$ is the natural log of face value of debt. $1 / \sigma_{E}$ is the inverse of the annualized stock return volatility. Excess Return is the difference between the stock's annual return and the CRSP value-weighted return. We follow Bharath and Shumway (2008) to calculate the excess return using market return as the benchmark given our focus on the part of the return that is not explained by the overall market return. ${ }^{4}$ Income/Assets is the ratio of net income to total asset. We winsorize all variables, except $E D F$, at the 1st and 99th percentiles to mitigate the influences of outliers. Table 2 reports summary statistics, including the mean, minimum, median, maximum, and standard deviation, for the entire sample. Panel A reports the variables used for the full sample. Panel B reports only the variables used for the mechanism analysis in Section 5 .

For the full period, the summary statistics show the range of our sample. An average firm in our sample has an expected default frequency $(E D F)$ of $6.19 \%$. The default rate is highly skewed to the right. While the median is zero, the maximum is a full $100 \% .{ }^{5}$ The standard deviation of $E D F$ is large at $18.9 \%$. Liquidity measured by Effective Spread (Quoted Spread) ranges from $0.03 \%(0.03 \%)$ to $6.76 \%(5.22 \%)$ with a mean value of $1.00 \%$ (1.21\%), consistent with existing literature. The Amihud measure (multiplied by $10^{6}$ ) averages 0.42 , and the mean of Zeros is $6.82 \%$.

The other firm variables look relatively standard and also have a reasonable degree of variation. ${ }^{6}$ For instance, the average market value of equity, Equity, is $\$ 3.1$ billion and ranges

\footnotetext{
4 We repeat the analysis with raw returns and the results are qualitatively the same.

5 We winsorize the distance-to-default $(D D)$ variable, but we do not winsorize $E D F$ because the value of $E D F$ is bounded. If we winsorize $E D F$, the maximum value of $E D F$ becomes $97.54 \%$.

${ }^{6}$ The statistics in the table are reported after winsorization, which is why the minimum and maximum are denser than the population. For instance, we report the minimum Debt to be $\$ 30,000$ as values of zero will be replaced. This also explains why the maximum Equity value is $\$ 63$ billion.
} 
from $\$ 23$ million to $\$ 63$ billion. The average face value of debt is $\$ 515$ million, and the average Excess Return is slightly over $5 \%$. Average return volatility of the stocks in our sample is $51.12 \%$. The average Income/Assets is -0.0076.

\section{Panel analysis}

Before turning to causal interpretations, we examine the general relation between liquidity and default risk. Understanding the empirical relation between liquidity and default risk provides useful insights itself. If, for instance, liquidity can help predict default, then suppliers, customers, and counterparties can use it to improve their contracting and risk management. We begin with simple distributions of $E D F$ s across liquidity groups. All four measures show a negative relation between liquidity and default risk. As other factors that are likely correlated with liquidity and default risk could be driving the relation, we move to multivariate regressions. Even so, the negative relation persists. We show the relation is true for most industries and is robust to different measures of liquidity.

\subsection{Univariate analysis}

We form portfolios by sorting stocks by their level of liquidity. In each year $t$, stocks are assigned into one of five groups based on their liquidity measure. We compute the portfolio EDF in year $t+1$ by taking the average of the $E D F$ across all stocks in the portfolio. Table 3 reports summary statistics for the $E D F$ across liquidity-sorted portfolios.

$E D F$ declines monotonically with stock liquidity. Firms in the liquid portfolios have lower expected default frequency. The results hold for all four measures of liquidity and are economically large. The 5-1 measure row reports the average $E D F$ difference between the least 
liquid and most liquid stock. The least liquid firms, those in the bottom quintile, are 9.21\% (Zeros) to $11.09 \%$ (Effective Spread) more likely to default in the following year compared with the most liquid quintile of stocks. The difference is statistically significant at the $1 \%$ level.

These results establish a negative relation between stock liquidity and default risk at the univariate level. However, some of the difference in default risk could be due to other firm characteristics. For instance, small firms can be riskier and have a higher default risk. These small firms are also more likely to have low stock liquidity due to greater information asymmetry.

\section{2. $\quad$ Multivariate analyses}

We extend the analysis to a multivariate setting. Bharath and Shumway (2008) argue that the functional form of the $E D F$ is important to capturing default risk, above and beyond the default risk's input variables. To control for the direct determinants of default risk, we follow Bharath and Shumway (2008) to include five control variables: $\operatorname{Ln}\left(\right.$ Equity), $\operatorname{Ln}\left(\right.$ Debt), $1 / \sigma_{E}$, Excess Return, and Income/Asset. We lag all independent variables by one year to mitigate the issue of reverse causality. ${ }^{7}$ Standard errors are clustered by firm. ${ }^{8}$ The baseline specification is defined as:

$$
\begin{aligned}
& E D F_{i, t}=\alpha+\beta \text { Liquidity }_{i, t-1}+\gamma_{1} \operatorname{Ln}\left(\text { Equity }_{i, t-1}+\gamma_{2} \operatorname{Ln}(\text { Debt })_{i, t-1}+\gamma_{3} 1 / \sigma_{E i, t-1}+\right. \\
& \gamma_{4} \text { Excess Return }_{i, t-1}+\gamma_{5} \text { Income } \text { Assets }_{i, t-1}+\theta^{\prime} \text { Firm }+\psi^{\prime} \text { Year }+ \\
& \text { Error }_{i, t}
\end{aligned}
$$

where Liquidity is either Effective Spread, Quoted Spread, Amihud, or Zeros measured for firm $i$ in year $t$-1. Firm and Year stand for vectors of firm and year fixed effects.

7 The results hold if we perform contemporaneous regressions.

${ }^{8}$ The statistical significance is similar if we cluster standard errors by industry, by year or by both. 
Table 4 presents the results from the $E D F$ regression analysis with firm and year fixed effects. Column 1 presents the results of the regression without a liquidity measure. Columns 2 to 5 report the results of regressions with Effective Spread, Quoted Spread, Amihud, and Zeros as liquidity measures, respectively. The negative relation between firm default risk and stock liquidity holds in the regression analysis. The results are consistent across all four measures of liquidity. The point estimates are statistically significant at the $1 \%$ level. The sizes of the coefficients are also economically important.

For instance, the coefficient on Effective Spread is 0.0135. A 1\% decrease in the effective spread (increase in liquidity) is associated with a 1.35\% decrease in default risk. To account for the variability of the Effective Spread, we can calculate the normalized coefficient by taking the product of the Effective Spread in Table 4 and the standard deviation of Effective Spread reported in Table 2, Panel A. The interpretation is that a one standard deviation decrease in Effective Spread is associated with a 1.66\% (0.0135 × 1.2330) level drop in default probability, equivalent to a drop of $26.89 \%$ over the sample mean of $E D F$ (i.e., 6.19\%). Likewise, when there is a one standard deviation decrease in Amihud, the expected decline in EDF is $1.01 \%$ (0.0072 $\times$ 1.4088), equivalent to a drop in the default probability of $16.39 \%$ relative to the sample average. For Zeros, the expected drop in default rate caused by a one standard deviation decrease in days with zero stock returns is $1.19 \%(0.0016 \times 7.4337)$, which is equal to a drop of $19.22 \%$ over the sample's average EDF.9

The results from the multivariate regression analysis support the univariate results in Subsection 3.1. The negative relation between liquidity and default risk persists even after controlling for firm characteristics known to be associated with default risk.

\footnotetext{
${ }_{9}$ In Internet Appendix Section A.1, we analyze the relation between actual bankruptcies and liquidity using a Cox proportional hazard rate model. We show that the negative relation also exists when evaluating actual bankruptcies.
} 
One potential concern is that the relation shown in Table 4, Panel A, is driven by one or a handful of industries. For instance, given the large number of bankruptcies following the dotcom bubble, our results could be limited to high-tech firms. To address this issue, we estimate the EDF regression separately for each of the Fama and French 12 industries. As we exclude financial firms, there are only 11 industries in the sample.

Panel B of Table 4 reports the results. Each row represents a regression conducted for a particular industry subset of firms. For instance, Row 1 is based on firms in the nondurables industry. For each industry, we perform four regressions, one for each of the liquidity measures. For brevity, we report only the coefficient and standard error, clustered by firm, for the liquidity variable from the regression. Not every coefficient is statistically significant, but, overall, the negative relation between liquidity and default risk holds across industries. For Quoted Spread, it is statistically significant for all 11 industries. For Effective Spread (Amihud and Zeros), ten (six and five) of the 11 industries show a statistically significant coefficient. The effects of liquidity on default risk are not purely driven by high-tech industries. They can also be found across the economy.

\section{Exogeneity}

Section 3 shows a relation between liquidity and default risk. However, multivariate analysis does not address the potential reverse causality problem. Empirically, identifying whether higher stock liquidity leads to lower default risk is difficult because the relation goes both ways. Liquidity could affect default risk, but default risk could also affect liquidity. Market makers demand higher returns for making markets in riskier assets by quoting wider spreads (Copeland and Galai, 1983). That is, market makers provide less liquidity in stocks with higher default risk. Even lagging independent variables is not sufficient to overcome the reverse causality problem. 
The identification strategy we implement to address the issue is the use of tick price decimalization as an exogenous shock to stock liquidity. We also conduct several tests, including difference-in-differences tests to identify the effect of liquidity on default probability in the following session.

Decimalization refers to the transition to quoting and trading securities in one penny increments from $1 / 16$ of a dollar in 2001. Prior to decimalization, the smallest price change for stock trading was $1 / 16$ of one dollar in a price quote. The SEC regulated that all stock markets within the US should convert all stock price quotes to decimal trading by April 9, 2001. With the implementation of decimalization, the minimum price change is $\$ 0.01$, which allows for tighter spreads between bid and ask prices.

Decimalization is widely used in prior literature as an exogenous positive shock to stock market liquidity (Fang, Noe, and Tice, 2009; Bharath, Jayaraman, and Nagar, 2013; Edmans, Fang, and Zur, 2013; Kang and Kim, 2013). It is a good candidate for an exogenous shock to liquidity for three reasons. First, the event is unlikely to be driven by firm default risk. Instead, the change was prompted by the SEC's effort to reduce security trading cost, encourage quote competition, and boost the US equity market's competitive edge relative to foreign markets. ${ }^{10}$ Second, stock liquidity improved significantly after decimalization, especially among actively traded stocks (Bessembinder, 2003; Furfine, 2003; Chordia, Roll, and Subrahmanyam, 2008). Third, large cross-sectional variation exists in the change in liquidity, allowing us to implement

\footnotetext{
${ }^{10}$ In the 1994 SEC report Market 2000: an examination of current equity market developments, the agency Staff expressed concern that 1/8th of a dollar tick size could "cause artificially wide spreads and hinder quote competition." The report also expressed concern that the $1 / 8$ th fraction pricing could hurt "the competitive posture of the US equity markets" compared with foreign equity markets. In March 1997, Rep. Michael Oxley introduced a bill in the US House of Representatives that would have directed the SEC to adopt decimal pricing for all equity securities. In September 2000, the SEC further mandated that the exchanges start implementing decimal pricing and finish implementation by April 2001. NYSE and Amex would replace the system of fractional pricing by January 29, 2001. Nasdaq decimalized shortly thereafter and finished implementing it by April 2001.
} 
a difference-in-differences analysis to test whether a larger increase in liquidity is associated with a greater decline in default risk.

We focus on the year before and the year after decimalization. A short window reduces concerns relating to reverse causality and allows us to better control for the impact of unobserved variables as significant changes in those variables are less likely to happen during a short window.

To make claims about how liquidity affects default risk, we employ a DID identification strategy. We compare the change in the default probability for two groups of firms that look similar except that they experience a significantly different change in liquidity around decimalization. The DID method controls for the impact of omitted and unobserved variables, and it removes biases driven by time trends.

We follow Fang, Tian, and Tice (2014) to construct a treatment group and a control group using propensity score matching. We rank all sample firms based on their changes in liquidity around decimalization and assign them into terciles. We retain firms in the first and third tercile. From here onward in this paper, we focus on the relative effective spread, Effective Spread.

We estimate a probit model in which the dependent variable is set to one for firms in the first tercile and zero for firms in the third tercile, and we use the predicted probabilities (propensity scores) to match firms in the two groups. The probit model includes Effective Spread and the same set of control variables as in Eq. (4), measured in the pre-decimalization year (2000). Each firm in the first tercile is matched to a firm in the third tercile with the closest propensity score and with a propensity score match within o.01. We retain all pairs in the case of multiple matching. This approach yields a treatment group and a matching control group with firms having very similar firm characteristics and liquidity prior to decimalization but experiencing a 
different degree of change in liquidity after decimalization. The treatment (control) group consists of firms with the highest (lowest) increase in stock liquidity decimalization.

The matching procedure produces seven hundred treatment-control pairs. ${ }^{11}$ The results of the probit regression are reported in Table 5, Panel A, Column 1. The probit model produces a pseudo $R$-squared of 0.1068 and a $p$-value from the chi-square test below 0.0001, suggesting that the model specification captures a significant amount of variation in the choice variable.

The validity of the DID estimator critically depends on the assumption that the underlying trends in the outcome variable is the same for both groups (parallel trend assumption). We follow Fang, Tian, and Tice (2014) and perform three diagnostic tests to verify that the assumption holds in this case.

The first diagnose test reruns the probit model reported in Table 5, Panel A, Column 1, except for the matched sample. The results are in Column 2. All of the explanatory variables are insignificant, and the likelihood ratio is lower than pre-match probit model results in Column 1. The interpretation is that no observable different characteristics exist between the treatment and control groups in the pre-decimalization year. The magnitude of the coefficient estimates in the post-match analysis are smaller, and no longer statistically significant, compared with that of the coefficients in the pre-match analysis, suggesting a weaker relation between firm characteristic differentials of the treatment and control groups. In addition, the pseudo $R$ squared drops drastically from 0.1068 prior to the matching to 0.0016 . The chi-square test has a $p$-value of 0.9556 on the pre-match probit model, suggesting that, overall, all coefficient estimates on independent variables are not statistically significantly different from zero.

The analysis in Table 5, Panel A, Column 2, dampens the concern that the less-affected control group is not fundamentally different from the more-affected treatment group. However, an omitted variable could be correlated with both how decimalization affects different stocks

\footnotetext{
${ }^{11}$ The number of matched pairs is larger than that in Fang, Tian, and Tice (2014), because fewer firms have missing data for $E D F$ than for innovation variables.
} 
and $E D F$. Therefore, complete exogeneity is challenging to establish. In the ideal setting, a group of stocks not subject to the tick size change could be used as a control group. Prior to the 2001 decimalization, a short pilot program had a staggered introduction and so created a natural unaffected control group. While the time period is short, we show in the Internet Appendix that the main results in this paper hold in the pilot program.

The second test compares the propensity scores of the treatment and control groups. Table 5, Panel B, reports the distribution of the propensity scores for both groups and their difference. The two groups' propensity scores line up closely. The average distance between the treatment firms' and matching control firms' propensity score is less than -0.00o1, with a maximum (minimum) of o (-0.0092).

The last diagnostic test performs a $t$-test on the differences between the two groups' predecimalization characteristics. Panel $\mathrm{C}$ of Table 5 shows no statistically significant differences between the treatment group and the control group of firms' characteristics that affect firm's $E D F$. Moreover, the two groups have a similar level of liquidity prior to decimalization, even if the decimalization affects them differently. The diagnostic tests suggest that the propensity score matching method is able to dampen the potentially confounding firm differences known to affect default risk, helping to alleviate concerns that the results are not driven by general time trends.

Panel D of Table 5 shows that significant differences in $E D F$ exist between the treatment and control firms after decimalization. We calculate the DID estimator and corresponding $t$-statistics and report the results in Table 5, Panel E. We calculate the change of EDF from the predecimalization year to the post-decimalization year $(\triangle E D F)$ for both the treatment and the control firms. We next examine the difference in $\triangle E D F$ between the two groups. On average, a treatment group firm experiences a larger decline in default risk by $8.97 \%$ compared with a control group firm. The difference is statistically significant at the $1 \%$ level. 
Finally, we perform the DID analysis in a regression framework as follows:

$$
E F_{i, t}=\alpha+\beta_{1} \text { Treatment }_{i} * \text { After }_{t}+\beta_{2} \text { Treatment }_{i}+\beta_{3} \text { After }_{t}+\gamma \text { Controls }_{i, t}+\text { Error }_{i, t},
$$

where Treatment is a dummy variable equal to one (zero) if a stock is part of the treatment (control) group, After is a dummy variable equal to one for 2002 (post-decimalization year) and zero for 2000, and Treatment ${ }^{*}$ After is the interaction between these two variables.

The control variables are the same as those used in the probit model in Table 5, Panel A, measured in the pre-decimalization year. In addition, we explicitly control for any firm value changes surrounding decimalization (Fang, Noe, and Tice, 2009). We include in the regression specification the change of Tobin's $q$ from pre-decimalization to post-decimalization interacted with the After indicator variable. As the change in Tobin's $q$ is realized only post-decimalization, we interact it with the After indicator so the variable can impact only the post-decimalization observations. Any differential change in liquidity due to an increase in Tobin's q should be captured by Tobin's $q$. Standard errors are clustered by firm. The Column 2 specification includes industry fixed effects.

The results are in Table 5, Panel F. The statistical significant and negative coefficients of 0.062 for Treatment ${ }^{*}$ After indicates that the treatment firms experience a larger drop of $6.2 \%$ in $E D F$ after the decimalization compared with the control group. The results consistently show that an increase in liquidity lowers $E D F .{ }^{12}$

${ }_{12}$ One could be concerned that improved liquidity increases the stock price, so liquidity will mechanically increase as the Effective Spread measure has stock price in the denominator. While such an effect would be small, to ensure that it does not drive the results we repeat the analyses in Table 5, Panel $\mathrm{F}$, for the subgroup of stocks in which the stock price does not rise post-decimalization. The results are qualitatively the same and keep their statistical significance.

In the Internet Appendix, we report two robustness tests of the main result. In Subsection A2.1, we implement a difference-in-differences analysis around a 2000 decimalization pilot program. In Subsection A2.2, we conduct the difference-in-differences analysis around the 1997 tick size reduction from 8ths to 16ths. Both alternative approaches result in qualitatively similar findings as seen in Table 5 , Panel F. 
If stock liquidity can reduce the risk of default, the effect should be largest as a firm nears default. To test this conjecture, we divide the matched sample into four groups based on the size of the pre-decimalization $E D F$ and run the DID regression from Eq. (5) for each group separately. Table 6 reports the results. Column 1 reports the analysis conducted on firms with the highest $E D F$ in 2000, and the results in Column 4 come from firms with the lowest $E D F$ in 2000. The statistical significance and magnitude of coefficients on Treatment ${ }^{*}$ After declines monotonically from the group with the highest $E D F$ to the group with the lowest $E D F$. The coefficient for the highest $E D F$ firm group is -0.1464 and is statistically significant at the $5 \%$

level. For the second group, the coefficient magnitude falls to -0.0976 and is statistically significant at the $1 \%$ level. The third group coefficient magnitude falls further to -0.0539 but remains statistically significant at the $1 \%$ level. For the lowest $E D F$ group, the coefficient magnitude drops further, to -0.0345. The evidence supports the conjecture that the effect of stock liquidity on default risk is more pronounced for firms with higher pre-decimalization $E D F$.

\section{Possible mechanisms}

In this section, we investigate possible explanations for why liquidity can reduce default risk. We first provide further evidence that the linkage is not mechanical. Thereafter, we explore two possible channels through which stock liquidity affects firm default risk: information efficiency and governance. We find evidence that both channels work. We show, in a horse race that the informational efficiency channel plays a larger role.

\subsection{Is the relation between liquidity and default risk mechanical?}


Default occurs when a firm is unable to meet its debt obligations or when its asset value falls below the debt value. Fang, Noe, and Tice (2009) provide evidence that, compared with their low liquidity counterparties, firms with liquid stocks tend to have higher firm value, leading to lower likelihood of bankruptcy. The negative relation between liquidity and default probability could simply be a direct result of the firm value effect. To address a mechanical relation between firm value increasing and, therefore, default risk decreasing, we already include as a control variable in the Eq. (5) specification the change in Tobin's q.

To more closely examine the role of firm value in our results, we re-estimate the DID regression in Eq. (5) for subsamples of firms with different changes in firm value around decimalization. We divide the matched sample into two subsamples based on the direction of the change of equity value or debt value around decimalization. If the low default risk is mechanically driven by higher firm value, we expect to see the relation more pronounced among firms with positive (negative) change in equity (debt) value. The results are reported in Table 7.

Column 1 includes only the matched sample of firms with a zero or negative change of Ln(Equity). In Column 2 the sample includes only firms with positive change of Ln(Equity). The coefficient on Treatment ${ }^{*}$ After is negative and statistically significant at the $1 \%$ level in Column 1, and it is statistically insignificant in Column 2. We calculate a $Z$-statistic to formally test whether the coefficient on Treatment ${ }^{*}$ After is different between the analysis in Column 1 and 2. The $Z$-statistic shows that the two coefficients are statistically significantly different from each other. The differential coefficient indicates that the effect of liquidity on EDF is more pronounced for firms with negative change of equity value. This is counter to the direct effect suggesting that the effect should be larger when $\operatorname{Ln}$ (Equity) increases.

Column 3 presents the DID regression results for the subsample with a non-negative change in $\operatorname{Ln}(D e b t)$, and Column 4 is for firms with negative change in $\operatorname{Ln}(D e b t)$. The coefficient on Treatment ${ }^{*}$ After is negative and statistically significant at the $1 \%$ level in Column 3 , and 
statistically insignificant in Column 4, suggesting that the effect of stock liquidity on EDF is larger for firms with increasing $\operatorname{Ln}($ Debt). The results further indicate that the effect of liquidity on $E D F$ is not through firm value, i.e., the relation between liquidity and $E D F$ is not mechanical. ${ }^{13}$

\subsection{Informational efficiency}

Subrahmanyam and Titman (2001) argue that higher liquidity enhances the informational efficiency of stock prices by inducing more informed trading. Although managers are most informed of their own firms' fundamentals and investment opportunities, outside investors can possess better information on other price-relevant factors, such as the macroeconomic and industry outlook and competitors' strategies, which is transmitted into stock prices through their trading. Managers tend to listen to the information from the financial market because it is accessible and cheap (Dow and Gorton, 1997). As a result, managers use the information in stock prices to guide their decision making and investments (Luo, 2005; Chen, Goldstein, and Jiang, 2007; Bakke and Whited, 2010), which, in turn, affects a firm's future cash flow and its ability to meet its debt obligation.

We employ two measures to capture price efficiency. The first measure is stock return autocorrelation (Correlation), the absolute value of the first-order return autocorrelation of weekly returns. A smaller autocorrelation indicates that the stock price process is closer to a random walk and, thus, the price is more efficient. The second measure is a price delay measure (Hou and Moskowitz, 2005), which captures the average delay with the stock price movements

${ }_{13}$ In unreported results, we do the analysis for two inputs of $E D F$, Return and $\sigma_{E}$. For the Return input, the largest magnitude decrease is associated with a positive change of stock return as the direct static effect would suggest. For $\sigma_{E}$, the coefficient on Treatment*After is statistically significant only for firms with increasing $\sigma_{E}$, which is associated with the opposite effect expected from the positive relation between $\sigma_{E}$ and $E D F$. The results suggest that the relation between liquidity and $E D F$ is complex and that the effect of liquidity on any one input variable does not mechanically determine the overall effect. 
in response to information. Price Delay is calculated as 1 - $(R$-squared of restricted model / $R$ squared of nonrestricted model). The nonrestricted model is specified as $r_{i, t}=\alpha_{i}+\beta_{i} R_{m, t}+$ $\sum_{n=1}^{4} \delta_{i}^{(-n)} R_{m, t-n}+\varepsilon_{i, t}$, where $r_{i, t}$ is the return on stock $i$ in week $t$ and $R_{m, t}$ is the return on the CRSP value-weighted market index in week $t$. The restricted model constrains that $\delta_{i}^{(-n)}=0$. We compute the price efficiency measures for each stock for the pre- and post-decimalization year and take the difference to obtain the change in the price efficiency measure from predecimalization year to post-decimalization year ( $\Delta$ Correlation and $\Delta$ Price Delay). Table 8, Panel A, reports the statistics and the corresponding $t$-statistics.

Compared with the control firms, after decimalization, firms in the treatment group experience a statistically significant larger drop of $2.92 \%$ and $6.25 \%$ in Correlation and Price Delay, respectively. The results are consistent with firms experiencing an increase in price efficiency due to higher liquidity decreasing default risk.

In the regression specification, we regress $\triangle E D F$ on the change in a price efficiency measure and the change of control variables for the matched sample constructed in Table $5 \cdot{ }^{14}$ The change is from pre-decimalization year (2000) to post-decimalization year (2002) for each firm. The control variables are the same as used throughout the paper: changes in $\operatorname{Ln}($ Equity), $\operatorname{Ln}(D e b t)$, $1 / \sigma_{E}$, Excess Return, Income/Assets, and Tobin's $q$. The results are shown in Table 8, Panel B. Column 1 reports $\Delta$ Correlation and Column 2 reports $\Delta$ Price Delay.

The coefficient of interest, the change in the price efficiency measure, is statistically significant and positive for each specification. An improvement in price efficiency is associated with a decline in $E D F$. For example, the coefficient on $\triangle$ Correlation is 0.2088. A firm in the treatment group that experiences a larger decline of 0.0292 in Correlation surrounding the decimalization event translates into a further reduction of $E D F$ by $0.61 \%(0.2088 \times 0.0292)$

\footnotetext{
${ }^{14}$ As the regression is now performed on changes, we no longer need to interact $\Delta$ Tobin's $q$ with the After indicator.
} 
compared with firms in the control group. ${ }^{15}$ The magnitude varies across the two price efficiency measures, but all suggest that the informational efficiency of price is a channel through which stock liquidity affects firm's default risk.

\subsection{Corporate governance}

Another possible channel through which stock liquidity reduces default risk is corporate governance. Maug (1998) models the incentives of monitoring by large shareholders. He argues that liquidity makes corporate governance more effective if monitoring is costly. Admati and Pfleiderer (2009) also analyze the threat of exit as an alternative mechanism of corporate governance. Their results support the notion that liquidity could enhance governance. Edmans and Manso (2011) show that liquidity increases blockholders' effectiveness in exerting corporate governance through disciplinary trading, which, as a result, induces a higher managerial effort. Edmans, Fang, and Zur (2013) show the causal effect of liquidity on improving corporate governance using decimalization as an exogenous shock. They find that liquidity facilitates block formation and encourages governing via trading (exit), although liquidity weakens blockholders' incentives for active intervention (voice). The overall effect is positive.

We employ two measures to capture governance, blockholder ownership (Block) and the number of blockholders (NBlock), using institutional ownership data from the Thomson Reuters Institutional (13F) Holdings database at Wharton Research Data Service. Block is calculated as the total holding by institutional blockholders who own no less than $5 \%$ of the shares outstanding at the end of each year, and NBlock is the number of the blockholders (Larcker, Richardson, and Tuna, 2007; Dittmar and Mahrt-Smith, 2007).

\footnotetext{
15 Multiply the coefficient on $\Delta$ Correlation by the difference-in-differences estimator of $\Delta$ Correlation.
} 
Similar to the analysis in Subsection 5.2, we first show that the shock to liquidity brought by decimalization is associated with more block holding in terms of the number of blockholders and their total holding. $\Delta$ Block is defined as the difference in total block holding between the pre-event and the post-event period. $\triangle$ NBlock is defined in similar manner. Table 9, Panel A, shows the difference-in-differences estimators for both $\Delta$ Block and $\Delta$ NBlock.

Blockholders as a group increase their holdings in treatment firms from $16.56 \%$ to $17.93 \%$ of shares outstanding following the change to trading in decimalization, compared with a change from $16.03 \%$ to $14.26 \%$ for control firms. The DID estimator is 3.14 percentage points, statistically significant at the $1 \%$ level. Results are qualitatively similar for the number of blockholders. The number blockholders in the treatment stocks increases by 0.34 more compared with the control stocks, with a $p$-value less than 0.0001 . Taken together, these results suggest that an improvement in liquidity attracts more blockholders and results in a subsequent increase in their aggregate ownership.

We next regress $\triangle E D F$ on the change in the blockholding measure and the change of control variables. The results are reported in Panel B of Table 9. Column 1 includes Block, and Column 2 includes NBlock. The coefficient of the change in Block (NBlock) is -0.1617 (-0.0079), suggesting that, compared with the control firms, an average firm in the treatment group that experiences a larger increase of $3.14 \%$ (34\%) in Block (NBlock) surrounding the decimalization can lead to a further reduction of $E D F$ by $0.51 \%(0.27 \%) .{ }^{16}$ The treatment stocks experience an additional drop in $E D F$ of $0.51 \%$ due to increased blockholding, which is equivalent to a decline of $3.08 \%$ over their pre-decimalization mean. Results for the number of blockholders are similar in terms of sign and the magnitude of the effects. The results show that improved corporate governance is a channel through which stock liquidity affects firm's default risk.

\footnotetext{
${ }^{16}$ Multiply the coefficient on $\Delta B$ lock ( $\triangle$ NBlock) by the difference-in-differences estimator of $\Delta$ Block $(\Delta$ NBlock), $-0.1617 \times 0.0314(-0.0079 \times 0.34)$.
} 
One concern regarding the governance channel is that the effective spread is not directly relevant to block formation and blockholder trading. To address this issue, we repeat the analysis by replacing the effective spread with a price impact measure. ${ }^{17}$ Price impact is a measure of liquidity that focuses on how a trade (buy or sell) affects the subsequent price change. It reflects the cost faced by traders, making it a relevant measure for large traders such as blockholders. We follow Bessembinder and Kaufman (1997) to calculate the price impact component of the relative effective spread. ${ }^{18}$ We first construct the matched sample based on the change of Price Impact surrounding the decimalization and then show that the shock to price impact brought by decimalization is associated with more block holding. The results in Table 9, Panels C and D, still support the corporate governance channel.

\subsection{Comparing mechanisms}

While the data show that both increasing price efficiency and improving corporate governance drive the results, it is unclear which mechanism is more important. We compare the two mechanisms through a horse race. We include measures for the two mechanisms in one regression specification. As there are different measures for each mechanism and these measures have divergent magnitudes, we use different combinations of the measures and implement a standardized regression. We subtract the dependent variable and all independent variables by their mean value and divide the difference by their standard deviation. For instance, we standardize $\triangle E D F$ by subtracting its mean value and dividing the difference by the standard deviation of $\triangle E D F$. The interpretation of a coefficient is the impact a one standard deviation change in the independent variable has on the dependent variable, in terms of a standard deviation variation.

\footnotetext{
${ }_{17}$ We thank an anonymous referee for suggesting the idea.

${ }^{18}$ See Table 1 for the calculation of Price Impact.
} 
We again use the matched sample constructed in Table 5 and regress the standardized $\triangle E D F$ (labeled as $\triangle E D F S T D$ ) on the standardized change of mechanism variables ( $\triangle$ Correlation $S T D$, $\triangle$ Price Delay $S T D, \triangle B l o c k S T D, \triangle N B l o c k S T D$ ) and the standardized change of control variables $\left[\Delta \operatorname{Ln}\left(\right.\right.$ Equity) STD, $\Delta \operatorname{Ln}\left(\right.$ Debt) STD, $\Delta\left(1 / \sigma_{E}\right) S T D, \Delta$ Excess Return STD, $\Delta$ Income/Assets STD, and $\Delta$ Tobin's $q$ ]. The results are reported in Table 10.

The table has four columns, one for each of the possible combinations of the mechanismbased variables. In Columns 1 and 2, we use $\triangle$ Correlation STD as the price efficiency measure but two different blockholding measures, $\triangle B$ Block STD and $\triangle$ NBlock STD, respectively. Comparing the first two columns, the coefficients on $\triangle$ Correlation STD are almost the same (11\%), and the coefficients on $\triangle N B l o c k S T D$ and $\triangle B l o c k S T D$ are smaller in magnitude. Columns 3 and 4 contain $\triangle$ Price Delay $S T D$ as the price efficiency measure and $\triangle B l o c k S T D$ and $\triangle N B l o c k$ $S T D$ as the blockholding measure, respectively. The variable capturing price efficiency, $\triangle$ Price Delay STD, has the largest effect, with a coefficient of about 0.12. The coefficient of $\triangle B l o c k S T D$ (o.08) is statistically significant and larger in magnitude than the coefficient of $\triangle N b l o c k S T D$.

By comparing the results vertically in each column, we find that the price efficiency channel has higher explanatory power than the corporate governance channel. One standard deviation increase in $\Delta$ Correlation ( $\triangle$ Price Delay) can lead to about an $11 \%(12 \%)$ increase in the standard deviation of $\triangle E D F$. The coefficients on $\triangle B l o c k S T D(\triangle N B l o c k S T D)$ are lower in magnitude than the coefficients on all the standardized change of price efficiency measures, suggesting that the explanatory power of the blockholders' governance channel is lower than that of the price efficiency channel.

\section{Conclusion}


This study examines whether and how stock liquidity affects firm default risk, as measured by expected default frequency. We show a strong negative relation between stock liquidity and firm bankruptcy risk. The relation is robust across multiple liquidity measures. To overcome reverse causality concerns, we use the decimalization event of 2001 as an exogenous shock to stock liquidity and employ a difference-in-differences analysis to show a negative effect of stock liquidity on firm default risk. The results consistently show that increasing stock liquidity decreases firm default risk. Moreover, the relation appears nonlinear. The impact is higher for firms with greater default risk in the pre-decimalization period.

The paper further explores the underlying mechanism through which stock liquidity affects default risk. We provide support that increased price efficiency and improved corporate governance are the two channels. A horse race between the mechanisms shows that the informational efficiency channel is more important than the governance channel.

Prior work shows a positive link between liquidity and firm value. Firms with higher firm value are less likely to miss their debt obligation, leading to a concern that the negative relation between liquidity and default probability is mechanical via increased firm value. We show that, even after controlling for the firm value channel, increasing stock liquidity reduces default risk.

Default is costly for the firm, its investors, and the real economy. Market structures that can decrease its likelihood are valuable and should be considered by regulators. This paper shows that decreasing the minimum tick size, i.e., increasing liquidity, can decrease the likelihood of firm default. Future research should evaluate other possible market designs that can be used to lower the likelihood of default and avoid its associated costs. 


\section{References}

Admati, A. R., Pfleiderer, P., 2009. The "Wall Street Walk" and shareholder activism: exit as a form of voice. Review of Financial Studies 22, 2645-2685.

Amihud, Y., 2002. Illiquidity and stock returns: crosssection and timeseries effects. Journal of Financial Markets 5, 31-56.

Baker, M., Stein, J. C., Wurgler, J., 2003. When does the market matter? Stock prices and the investment of equity-dependent firms. Quarterly Journal of Economics 118, 969-1006.

Bakke, T. E., Whited, T. M., 2010. Which firms follow the market? An analysis of corporate investment decisions. Review of Financial Studies 23, 1941-1980.

Bessembinder, H., 2003. Trade execution costs and market quality after decimalization. Journal of Financial and Quantitative Analysis 38, 747-777.

Bessembinder, H., Kaufman, H. M., 1997. A comparison of trade execution costs for NYSE and Nasdaq-listed stocks. Journal of Financial and Quantitative Analysis 32, 287-310.

Bharath, S. T., Jayaraman, S., Nagar, V., 2013. Exit as governance: an empirical analysis. Journal of Finance 68, 2515-2547.

Bharath, S. T., Shumway, T., 2008. Forecasting default with the Merton distance-to-default model. Review of Financial Studies 21, 1339-1369.

Bhide, A., 1993. The hidden costs of stock market liquidity. Journal of Financial Economics 34, $31-51$.

Bond, P., Edmans, A., Goldstein, I., 2012. The real effects of financial markets. Annual Review of Financial Economics 4, 339-360.

Campbell, J. Y., Hilscher, J., Szilagyi, J., 2008. In search of distress risk. Journal of Finance 63, 2899-2939.

Chen, Q., Goldstein, I., Jiang, W., 2007. Price informativeness and investment sensitivity to stock price. Review of Financial Studies 20, 619-650.

Chordia, T., Roll, R., Subrahmanyam, A., 2001. Market liquidity and trading activity. Journal of Finance 56, 501-530.

Chordia, T., Roll, R., Subrahmanyam, A., 2008. Liquidity and market efficiency. Journal of Financial Economics 87, 249-268.

Copeland, T. E., Galai, D., 1983. Information effects on the bid-ask spread. Journal of Finance 38, 1457-1469.

Crosbie, P., Bohn, J., 2003. Modeling default risk. Research report. KMV, LLC, San Francisco, CA. 
Dittmar, A., Mahrt-Smith, J., 2007. Corporate governance and the value of cash holdings. Journal of Financial Economics 83, 599-634.

Dow, J., Gorton, G., 1997. Stock market efficiency and economic efficiency: is there a connection? Journal of Finance 52, 1087-1129.

Duffie, D., Saita, L., Wang, K., 2007. Multi-period corporate default prediction with stochastic covariates. Journal of Financial Economics 83, 635-665.

Edmans, A., 2009. Blockholder trading, market efficiency, and managerial myopia. Journal of Finance 64, 2481-2513.

Edmans, A., Fang, V. W., Zur, E., 2013. The effect of liquidity on governance. Review of Financial Studies 26, 1443-1482.

Edmans, A., Manso, G., 2011. Governance through trading and intervention: a theory of multiple blockholders. Review of Financial Studies 24, 2395-2428.

Fang, V. W., Noe, T. H., Tice, S., 2009. Stock market liquidity and firm value. Journal of Financial Economics 94, 150-169.

Fang, V. W., Tian, X., Tice, S., 2014. Does stock liquidity enhance or impede firm innovation? Journal of Finance 69, 2085-2125.

Furfine, C., 2003. Decimalization and market liquidity. Economic Perspectives 27, 2-12.

Goldstein, I., Guembel, A., 2008. Manipulation and the allocational role of prices. Review of Economic Studies 75, 133-164.

Goldstein, M. A., Kavajecz, K. A., 200o. Eighths, sixteenths, and market depth: changes in tick size and liquidity provision on the NYSE. Journal of Financial Economics 56, 125-149.

Goyenko, R. Y., Holden, C. W., Trzcinka, C. A., 2009. Do liquidity measures measure liquidity? Journal of Financial Economics 92, 153-181.

Hasbrouck, J., 2010. The best bid and offer: a short note on programs and practices. Unpublished working paper. New York University, New York.

Holden, C. W., Subrahmanyam, A., 1992. Long-lived private information and imperfect competition. Journal of Finance 47, 247-270.

Holmström, B., Tirole, J., 1993. Market liquidity and performance monitoring. Journal of Political Economy 101, 678-709.

Hou, K., Moskowitz, T. J., 2005. Market frictions, price delay, and the crosssection of expected returns. Review of Financial Studies 18, 981-1020.

Kang, M. J., Kim, Y. H., 2013. Stock market liquidity and short-termism-driven CEO turnover. Unpublished working paper. Nanyang Business School, Singapore. 
Kealhofer, S., Kurbat, M., 2001. The default prediction power of the Merton approach, relative to debt ratings and accounting variables. Unpublished working paper. KMV LLC, San Francisco, CA.

Larcker, D. F., Richardson, S. A., Tuna, I., 2007. Corporate governance, accounting outcomes, and organizational performance. Accounting Review 82, 963-1008.

Lee, C., Ready, M. J., 1991. Inferring trade direction from intraday data. Journal of Finance 46, $733-746$.

Lesmond, D. A., Ogden, J. P., Trzcinka, C. A., 1999. A new estimate of transaction costs. Review of Financial Studies 12, 1113-1141.

Luo, Y., 2005. Do insiders learn from outsiders? Evidence from mergers and acquisitions. Journal of Finance 60, 1951-1982.

Maug, E., 1998. Large shareholders as monitors: is there a trade-off between liquidity and control? Journal of Finance 53, 65-98.

Merton, R. C., 1974. On the pricing of corporate debt: the risk structure of interest rates. Journal of Finance 29, 449-470.

Norli, Ø., Ostergaard, C., Schindele, I., 2015. Liquidity and shareholder activism. Review of Financial Studies 28, 486-520.

Ozdenoren, E., Yuan, K., 2008. Feedback effects and asset prices. Journal of Finance 63, 19391975 .

Polk, C., Sapienza, P., 2009. The stock market and corporate investment: a test of catering theory. Review of Financial Studies 22, 187-217.

Subrahmanyam, A., Titman, S., 2001. Feedback from stock prices to cash flows. Journal of Finance 56, 2389-2413.

Vassalou, M., Xing, Y., 2004. Default risk in equity returns. Journal of Finance 59, 831-868. 
Table 1

Variable definitions.

\begin{abstract}
Variable Definition
Effective Spread Annual relative effective spread. Relative effective spread is twice the difference between the execution price and the midpoint of the prevailing best bid-ask quote divided by the midpoint of the prevailing best bid-ask quote, multiplied by one hundred, and measured over one year.

Quoted Spread Annual relative quoted spread multiplied by one hundred. Relative quoted spread is the best bid-ask spread divided by the midpoint of the best bid-ask quote. Measured over one year.

Amihud Annual Amihud measure. Annual average of the daily ratio of absolute value of stock return divided by dollar trading volume, multiplied by one million.

Zeros $\quad$ Proportion of days with zero returns, multiplied by one hundred. Measured over one year.

DD Distance-to-default, calculated following Merton (1974) and Bharath and Shumway (2008).

EDF Expected default frequency, computed as $N(-D D)$, where $N($.$) is the cumulative$ standard normal distribution function.

Equity Market value of equity (in millions of dollars) calculated as the product of the number of shares outstanding and stock price at the end of the year.

Debt Face value of debt, in millions of dollars, computed as the sum of debt in current liabilities (Compustat quarterly data \#45) and one-half of long-term debt (Compustat quarterly data \#51).

Excess Return Annual excess return, calculated as the difference between firm stock return and market return over the same period.

$\sigma_{E} \quad$ Annualized stock return volatility computed as the standard deviation of stock monthly returns over the prior year.

Income /Assets Ratio of net income (Compustat quarterly data \#69) to total asset (Compustat quarterly data \#44).
\end{abstract}

Correlation Absolute value of the correlation between contemporaneous weekly stock returns and the one-week lagged weekly stock returns.

Price Delay 1- $(R$-squared of restricted model / $R$-squared of nonrestricted model). The nonrestricted model is specified as $r_{i, t}=\alpha_{i}+\beta_{i} R_{m, t}+\sum_{n=1}^{4} \delta_{i}^{(-n)} R_{m, t-n}+\varepsilon_{i, t}$, where $r_{i, t}$ is the return on stock $i$ in week $t, R_{m, t}$ is the return on Center for Research in Security Prices (CRSP) value-weighted market index in week $t$. The restricted model constrains that $\delta^{(-n)}=0$.

Price Impact Price impact component of the relative effective spread. It is measured as Price Impact $t_{i t}$ $=100 \times L R_{i t}\left(P i_{t+n}-M_{i t}\right) / M_{i t}$, where $P i_{t+n}$ denotes the first trade price observed at least 30 minutes after the trade for which price impact is measured, $M_{i t}$ is the midpoint of the matched prevailing best bid-ask quote, and $L R_{i t}$ is an indicator variable that equals one for buyer-initiated trade and negative one for seller-initiated trade.

Block Aggregate percentage ownership of blockholders who hold at least 5\% of total common shares outstanding at the end of the year.

NBlock Number of block owners who hold at least $5 \%$ of total common shares outstanding at the end of the year.

Tobin's $q \quad$ Market value of assets over book value of assets calculated from Compustat: (ATQ $C E Q Q+C S H O Q \times P R C C Q) / A T Q$ where $A T Q$ is total asset (Compustat quarterly data 
\#44), CEQQ is total common equity (Compustat quarterly data \#59), CSHOQ is common shares outstanding (Compustat quarterly data \#61), and PRCCQ is stock price at the end of the quarter. 
Table 2

Summary statistics.

The table reports summary statistics for the sample firm-year observations. The variables are defined in Table 1. Panel A contains 51,527 firm-year observations between 1993 and 2013. The sample period for $D D$ and $E D F$ is 1994-2014. Panel B contains 5,428 firm-year observations for the decimalization sample, in 2000 and 2002. The descriptive statistics are the mean, minimum, median, maximum, and standard deviation of the key variables.

\begin{tabular}{|c|c|c|c|c|c|c|}
\hline Variable & $N$ & Mean & Minimum & Median & Maximum & Standard deviation \\
\hline \multicolumn{7}{|c|}{ Panel A: Full sample variables } \\
\hline Effective Spread & 51,527 & 0.9961 & 0.0262 & 0.4996 & 6.7551 & 1.2330 \\
\hline Quoted Spread & 51,527 & 1.2059 & 0.0336 & 0.6899 & 5.2183 & 1.2842 \\
\hline Amihud & 51,527 & 0.4154 & 0.0000 & 0.0129 & 10.2386 & 1.4088 \\
\hline Zeros & 51,527 & 6.8188 & 0.0000 & 3.9683 & $33 \cdot 3333$ & 7.4337 \\
\hline$D D$ & 51,527 & $7 \cdot 3415$ & -1.9667 & 6.0064 & 30.5048 & 6.1772 \\
\hline$E D F$ & 51,527 & 0.0619 & 0.0000 & 0.0000 & 1.0000 & 0.1886 \\
\hline Equity & 51,527 & $3,111.22$ & 22.92 & 509.42 & $62,816.52$ & $8,672.40$ \\
\hline Debt & 51,527 & $515 \cdot 31$ & 0.03 & 68.64 & $8,865 \cdot 50$ & $1,333 \cdot 55$ \\
\hline Excess Return & 51,527 & 0.0543 & -0.9687 & -0.0476 & $3 \cdot 3550$ & 0.6659 \\
\hline$\sigma_{E}$ & 51,527 & 0.5112 & 0.1116 & 0.4212 & 1.9445 & 0.3350 \\
\hline Income/Assets & 51,527 & -0.0076 & -0.3197 & 0.0081 & 0.0885 & 0.0603 \\
\hline \multicolumn{7}{|c|}{ Panel B: Decimalization period variables } \\
\hline Correlation & 5,795 & 0.1296 & 0.0013 & 0.1121 & 0.4239 & 0.0964 \\
\hline Price Delay & 5,795 & 0.4849 & 0.0222 & 0.4468 & 0.9992 & 0.3005 \\
\hline Block & 5,795 & 0.1487 & 0 & 0.1224 & 0.8754 & 0.1400 \\
\hline NBlock & 5,795 & 1.6835 & $\mathrm{O}$ & 1 & 9 & 1.4810 \\
\hline
\end{tabular}


Table 3

Distribution of expected default frequency $(E D F)$ by liquidity groups.

The table reports the distribution of $E D F$ across five groups of stocks formed on liquidity measures during the sample period from 1994 to 2014. For each year, stocks are assigned into one of the five groups based on their liquidity measure. Group 1 consists of stocks with the highest liquidity, and stocks in group 5 are the least liquid. For each group, we report the average $E D F$. The liquidity measures are Effective Spread, Quoted Spread, Amihud, and Zeros. Table 1 defines the variables. The 5-1 row reports the average $E D F$ difference between the least liquid and most liquid stocks. Below in parentheses is the $t$-statistic. *, ***, and ${ }^{* * *}$ indicate statistical significance at the $10 \%, 5 \%$, and $1 \%$ level, respectively.

\begin{tabular}{lcccc}
\hline \multirow{2}{*}{ Liquidity measures } & \multicolumn{4}{c}{ EDF } \\
\cline { 2 - 5 } \multicolumn{1}{c}{$\begin{array}{c}\text { Effective Spread } \\
(1)\end{array}$} & $\begin{array}{c}\text { Quoted Spread } \\
(2)\end{array}$ & $\begin{array}{c}\text { Amihud } \\
(3)\end{array}$ & $\begin{array}{c}\text { Zeros } \\
(4)\end{array}$ \\
\hline 1 (most liquid) & 0.0098 & 0.0107 & 0.0148 & 0.0206 \\
3 & 0.0268 & 0.0260 & 0.0286 & 0.0301 \\
4 & 0.0486 & 0.0489 & 0.0491 & 0.0473 \\
5 (least liquid) & 0.0751 & 0.0746 & 0.0768 & 0.0721 \\
& 0.1207 & 0.1209 & 0.1114 & 0.1126 \\
$5^{-1}$ & & & & \\
$t$-statistic & $0.1109^{* * *}$ & $0.1102^{* * *}$ & $0.0966^{* * *}$ & $0.0921^{* * *}$ \\
\hline
\end{tabular}




\section{Table 4}

Regressions of default risk on stock liquidity.

The table presents ordinary least squares (OLS) regressions of default risk on liquidity measures. There are 51,527 firm-year observations between 1994 and 2014. The dependent variable is the expected default frequency $(E D F)$. Panel A reports the overall results. Column 1 presents the results of the regression without a liquidity measure. Columns 2 to 5 report the results of regressions with Effective Spread, Quoted Spread, Amihud, and Zeros as liquidity measures, respectively. Other control variables are $\operatorname{Ln}$ (Equity), $\operatorname{Ln}$ (Debt), 1/ $\sigma_{E}$, Excess Return, and Income/Assets. We control for both firm and year fixed effects in all regressions. Panel B reports the coefficients for the four liquidity measures from OLS regressions with $E D F$ as the dependent variable for each of the Fama and French 12 industries. We control for both firm and year fixed effects in all regressions. See Table 1 for definitions of all variables. Standard errors are clustered at the firm level and are presented in parentheses. *, ${ }^{* *}$, and ${ }^{* * *}$ indicate statistical significance at the $10 \%, 5 \%$, and $1 \%$ level, respectively.

\begin{tabular}{|c|c|c|c|c|c|}
\hline \multicolumn{6}{|c|}{ Panel A: OLS specifications } \\
\hline \multirow{2}{*}{ 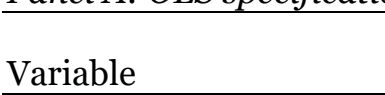 } & \multicolumn{5}{|c|}{ Dependent variable: $E D F_{t}$} \\
\hline & $(1)$ & (2) & (3) & (4) & (5) \\
\hline$\overline{\text { Effective Spread }}_{-1}$ & & $\begin{array}{l}0.0135^{* * *} \\
(0.0011)\end{array}$ & & & \\
\hline Quoted Spread $_{t-1}$ & & & $\begin{array}{c}0.0243^{* * *} \\
(0.0019)\end{array}$ & & \\
\hline Amihud $_{t-1}$ & & & & $\begin{array}{c}0.0072^{* * *} \\
(0.0010)\end{array}$ & \\
\hline $\operatorname{Zeros}_{t-1}$ & & & & & $\begin{array}{c}0.0016^{* * *} \\
(0.0003)\end{array}$ \\
\hline $\operatorname{Ln}(\text { Equity })_{t-1}$ & $\begin{array}{c}-0.0279^{* * *} \\
(0.0021)\end{array}$ & $\begin{array}{c}-0.0236^{* * *} \\
(0.0021)\end{array}$ & $\begin{array}{c}-0.0162^{* * *} \\
(0.0021)\end{array}$ & $\begin{array}{c}-0.0259^{* * *} \\
(0.0021)\end{array}$ & $\begin{array}{c}-0.0240^{* * * *} \\
(0.0021)\end{array}$ \\
\hline $\operatorname{Ln}(\text { Debt })_{t-1}$ & $\begin{array}{l}0.0104^{* * *} \\
(0.0008)\end{array}$ & $\begin{array}{l}0.0105^{* * *} \\
(0.0008)\end{array}$ & $\begin{array}{l}0.0105^{* * *} \\
(0.0008)\end{array}$ & $\begin{array}{l}0.0105^{* * *} \\
(0.0008)\end{array}$ & $\begin{array}{l}0.0101^{* * *} \\
(0.0008)\end{array}$ \\
\hline $1 / \sigma_{E t-1}$ & $\begin{array}{c}-0.0138^{* * *} \\
(0.0007)\end{array}$ & $\begin{array}{c}-0.0138^{* * *} \\
(0.0007)\end{array}$ & $\begin{array}{c}-0.0138^{* * *} \\
(0.0007)\end{array}$ & $\begin{array}{c}-0.0139^{* * *} \\
(0.0007)\end{array}$ & $\begin{array}{c}-0.0146^{* * * *} \\
(0.0007)\end{array}$ \\
\hline Excess Return $_{t-1}$ & $\begin{array}{c}-0.0613^{* * *} \\
(0.0017)\end{array}$ & $\begin{array}{c}-0.0619^{* * *} \\
(0.0017)\end{array}$ & $\begin{array}{c}-0.0635^{* * *} \\
(0.0017)\end{array}$ & $\begin{array}{c}-0.0622^{* * *} \\
(0.0017)\end{array}$ & $\begin{array}{c}-0.0617^{* * * *} \\
(0.0017)\end{array}$ \\
\hline Income$/$ Assets $_{t-1}$ & $\begin{array}{c}-0.1597^{* * *} \\
(0.0266)\end{array}$ & $\begin{array}{c}-0.1560^{* * *} \\
(0.0265)\end{array}$ & $\begin{array}{c}-0.1481^{* * *} \\
(0.0266)\end{array}$ & $\begin{array}{c}-0.1596^{* * *} \\
(0.0265)\end{array}$ & $\begin{array}{c}-0.1561^{* * *} \\
(0.0266)\end{array}$ \\
\hline Intercept & $\begin{array}{c}0.1910^{* * *} \\
(0.0114)\end{array}$ & $\begin{array}{l}0.1507^{* * * *} \\
(0.0118)\end{array}$ & $\begin{array}{c}0.0820^{* * *} \\
(0.0134)\end{array}$ & $\begin{array}{l}0.1775^{* * * *} \\
(0.0115)\end{array}$ & $\begin{array}{c}0.1456^{* * *} \\
(0.0136)\end{array}$ \\
\hline Firm fixed effects & Yes & Yes & Yes & Yes & Yes \\
\hline Year fixed effects & Yes & Yes & Yes & Yes & Yes \\
\hline Number of observations & 51,527 & 51,527 & 51,527 & 51,527 & 51,527 \\
\hline Adjusted $R^{2}$ & 0.1680 & 0.1739 & 0.1771 & 0.1706 & 0.1693 \\
\hline
\end{tabular}


Table 4 Continued

Panel B: Within-industry regressions

\begin{tabular}{|c|c|c|c|c|c|c|}
\hline Industry name & Description & $\begin{array}{l}\text { Effective } \\
\text { Spread }\end{array}$ & $\begin{array}{l}\text { Quoted } \\
\text { Spread }\end{array}$ & Amihud & Zeros & $N$ \\
\hline Nondurables & $\begin{array}{l}\text { Food, tobacco, textiles, apparel, leather, } \\
\text { toys }\end{array}$ & $\begin{array}{l}0.0150^{* * *} \\
(0.0048)\end{array}$ & $\begin{array}{l}0.0273^{* * *} \\
(0.0071)\end{array}$ & $\begin{array}{l}0.0029 \\
(0.0030)\end{array}$ & $\begin{array}{c}0.0003 \\
(0.0011)\end{array}$ & 3,412 \\
\hline Durables & $\begin{array}{l}\text { Cars, TVs, furniture, household } \\
\text { appliances }\end{array}$ & $\begin{array}{l}0.0117^{* *} \\
(0.0047)\end{array}$ & $\begin{array}{l}0.0292^{* * *} \\
(0.0122)\end{array}$ & $\begin{array}{l}0.0010 \\
(0.0055)\end{array}$ & $\begin{array}{c}0.0020 \\
(0.0013)\end{array}$ & 1,569 \\
\hline Manufacturing & $\begin{array}{l}\text { Machinery, trucks, planes, office } \\
\text { furniture, paper, commercial printing }\end{array}$ & $\begin{array}{l}0.0167^{* * *} \\
(0.0030)\end{array}$ & $\begin{array}{l}0.0416^{* * *} \\
(0.0056)\end{array}$ & $\begin{array}{l}0.0131^{* * *} \\
(0.0032)\end{array}$ & $\begin{array}{c}0.0022^{* * *} \\
(0.0008)\end{array}$ & 7,024 \\
\hline Energy & Oil, gas, and coal extraction and products & $\begin{array}{l}0.0082^{* *} \\
(0.0036)\end{array}$ & $\begin{array}{l}0.0166^{*} \\
(0.0095)\end{array}$ & $\begin{array}{l}0.0037 \\
(0.0062)\end{array}$ & $\begin{array}{c}0.0004 \\
(0.0011)\end{array}$ & 2,650 \\
\hline Chemicals & Chemicals and allied products & $\begin{array}{l}0.0108^{* * *} \\
(0.0049)\end{array}$ & $\begin{array}{l}0.0235^{*} \\
(0.0127)\end{array}$ & $\begin{array}{c}0.0030 \\
(0.0055)\end{array}$ & $\begin{array}{l}-0.0003 \\
(0.0018)\end{array}$ & 1,546 \\
\hline Business equipment & $\begin{array}{l}\text { Computers, software, and electronic } \\
\text { equipment }\end{array}$ & $\begin{array}{l}0.0121^{* * *} \\
(0.0029)\end{array}$ & $\begin{array}{l}0.0200^{* * *} \\
(0.0036)\end{array}$ & $\begin{array}{l}0.0063^{* * *} \\
(0.0018)\end{array}$ & $\begin{array}{l}0.0017^{* * *} \\
(0.0006)\end{array}$ & 9,578 \\
\hline Telecommunications & Telephone and television transmission & $\begin{array}{l}0.0197^{* *} \\
(0.0081)\end{array}$ & $\begin{array}{l}0.0315^{* * *} \\
(0.0117)\end{array}$ & $\begin{array}{l}0.0139^{*} \\
(0.0071)\end{array}$ & $\begin{array}{l}-0.0001 \\
(0.0021)\end{array}$ & 2,143 \\
\hline Utilities & Utilities & $\begin{array}{c}0.0037 \\
(0.0040)\end{array}$ & $\begin{array}{l}0.0349^{* *} \\
(0.0157)\end{array}$ & $\begin{array}{c}0.0075 \\
(0.0079)\end{array}$ & $\begin{array}{l}-0.0003 \\
(0.0005)\end{array}$ & 2,511 \\
\hline Shops & $\begin{array}{l}\text { Wholesale, retail, and some services } \\
\text { (laundries, repair shops) }\end{array}$ & $\begin{array}{l}0.0140^{* * *} \\
(0.0029)\end{array}$ & $\begin{array}{l}0.0288 * * * \\
(0.0053)\end{array}$ & $\begin{array}{l}0.0082^{* *} \\
(0.0032)\end{array}$ & $\begin{array}{l}0.0032^{* * *} \\
(0.0009)\end{array}$ & 6,792 \\
\hline Health & $\begin{array}{l}\text { Health care, medical equipment, and } \\
\text { drugs }\end{array}$ & $\begin{array}{l}0.0140^{* * *} \\
(0.0028)\end{array}$ & $\begin{array}{l}0.0175^{* * *} \\
(0.0040)\end{array}$ & $\begin{array}{l}0.0051^{* *} \\
(0.0020)\end{array}$ & $\begin{array}{l}0.0014^{* *} \\
(0.0007)\end{array}$ & 5,977 \\
\hline Other & $\begin{array}{l}\text { Mines, construction, building materials, } \\
\text { transportation, hotels, business services, } \\
\text { entertainment }\end{array}$ & $\begin{array}{l}0.0155^{* * *} \\
(0.0028)\end{array}$ & $\begin{array}{l}0.0216^{* * *} \\
(0.0048)\end{array}$ & $\begin{array}{l}0.0050^{* *} \\
(0.0024)\end{array}$ & $\begin{array}{l}0.0022^{* * *} \\
(0.0008)\end{array}$ & 8,325 \\
\hline
\end{tabular}




\section{Table 5}

Difference-in-differences analysis of the effect of stock liquidity on default risk.

The table presents a difference-in-differences analysis of stock liquidity on default risk surrounding the decimalization year. Panel A, Column 1, reports the results of a probit model based on the pre-matched firms in the treatment and the control groups. The dependent variable of the probit model equals one if the firm belongs to the treatment group and zero if the firm comes from the control group. The independent variables of the probit model are the control variables used in the expected default frequency (EDF) regression measured in the pre-decimalization year. Panel A, Column 2, reports the results of the same probit model based on the post-matched firms in the treatment and the control groups. Panel B reports statistical distributions of the propensity scores of the treatment and control groups and their differences. Panel $\mathrm{C}$ reports pre-decimalization variable averages for the treatment and control groups, the differences in means of each variable, and the corresponding $t$-statistics. Panel D reports postdecimalization variable averages for the treatment and control groups, the differences in means of each variable, and the corresponding $t$-statistics. Panel E reports the difference-in-differences estimator based on the matched sample. Panel F reports the results for the difference-in-differences regression based on the matched sample. Treatment is a dummy variable equal to one if a stock is in the treatment group and zero if in the control group. After is a dummy variable equal to one for 2002 (post-decimalization year) and zero for 2000. Treatment ${ }^{*} A f t e r$ is the interaction between these two variables. See Table 1 for variable definitions. Standard errors are clustered by firm and are shown in parentheses. * ${ }^{* *}$, and ${ }^{* * *}$ indicate statistical significance at the $10 \%, 5 \%$, and $1 \%$ level, respectively.

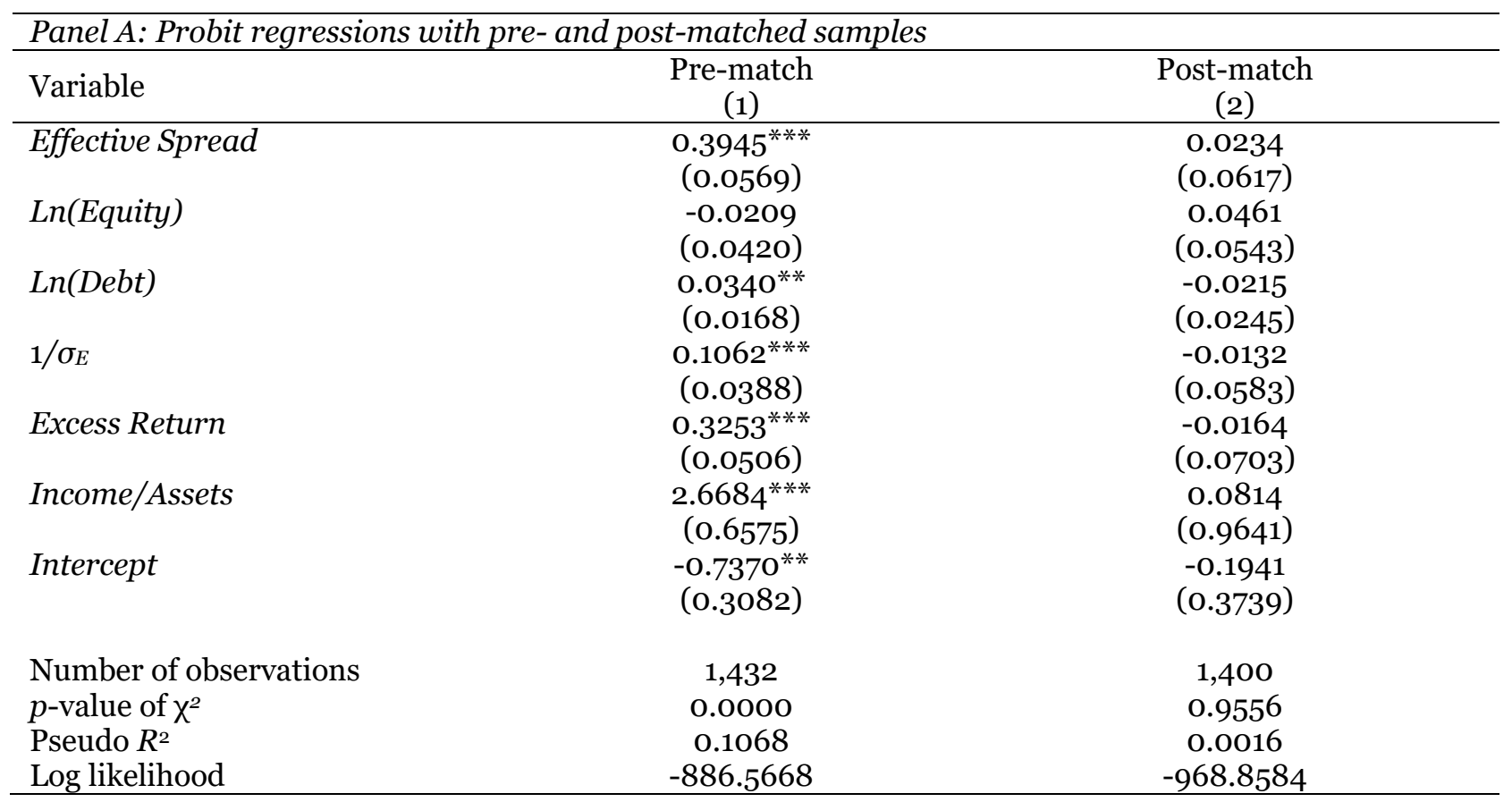

Panel B: Propensity scores distribution

\begin{tabular}{lcccccc}
\hline Group & $N$ & Mean & Minimum & Median & Maximum & Standard deviation \\
\hline Treatment & 700 & 0.5604 & 0.1043 & 0.4296 & 0.5409 & 0.6865 \\
Control & 700 & 0.5605 & 0.1060 & 0.4296 & 0.5407 & 0.6885 \\
Difference & 700 & 0.0000 & -0.0092 & -0.0004 & 0.0000 & 0.0004 \\
\hline
\end{tabular}


Table 5 Continued

Panel C: Differences in variables in pre-decimalization year

\begin{tabular}{lccccc}
\hline Variable & Treatment & Control & Difference & $t$-statistic & $p$-value \\
\hline Effective Spread & 1.6429 & 1.6124 & 0.0305 & 0.46 & 0.6478 \\
Ln(Equity) & 5.6413 & 5.6071 & 0.0342 & 0.47 & 0.6350 \\
Ln(Debt) & 3.3766 & 3.4991 & -0.1225 & -0.97 & 0.3303 \\
$1 / \sigma_{E}$ & 1.8663 & 1.9106 & -0.0443 & -0.84 & 0.4023 \\
Excess Return & 0.2379 & 0.2421 & -0.0042 & -0.10 & 0.9237 \\
Income/Assets & -0.001 & -0.0006 & -0.0004 & -0.16 & 0.8724 \\
Tobin's - & 2.0933 & 1.9552 & 0.1381 & 1.35 & 0.1758 \\
\hline
\end{tabular}

Panel D: Differences in variables in post-decimalization year

\begin{tabular}{lccccc}
\hline Variable & Treatment & Control & Difference & $t$-statistic & $p$-value \\
\hline Effective Spread & 0.8239 & 4.1281 & -3.3042 & -35.64 & $<0.0001$ \\
Ln(Equity) & 5.8113 & 5.5487 & 0.2626 & 3.87 & 0.0001 \\
Ln(Debt) & 3.3182 & 3.4938 & -0.1755 & -1.38 & 0.1687 \\
$1 / \sigma_{E}$ & 2.3195 & 2.2219 & 0.0977 & 1.55 & 0.1221 \\
Excess Return & 0.1968 & -0.0241 & 0.2209 & 9.22 & $<0.0001$ \\
Income/Assets & 0.0019 & -0.00971 & 0.0116 & 4.43 & $<0.0001$ \\
Tobin's & 1.7916 & 1.6674 & 0.1242 & 1.72 & 0.0859 \\
\hline
\end{tabular}

Panel E: Difference-in-differences estimator

\begin{tabular}{lcccccccc}
\hline \multirow{2}{*}{ Variable } & \multicolumn{2}{c}{ Treatment } & & \multicolumn{2}{c}{ Control } & \multirow{2}{*}{ Difference-in-differences } & \multirow{2}{*}{-statistic } & $p$-value \\
\cline { 2 - 3 } & Before & After & & Before & After & & & \\
\hline$E D F$ & 0.0889 & 0.0215 & & 0.1113 & 0.1336 & -0.0897 & -6.69 & $<0.0001$ \\
\hline
\end{tabular}


Table 5 Continued

Panel F: Difference-in-differences regression

\begin{tabular}{|c|c|c|}
\hline \multirow[b]{2}{*}{ Variable } & \multicolumn{2}{|c|}{ Dependent variable: $E D F_{t}$} \\
\hline & (1) & (2) \\
\hline Treatment ${ }^{*}$ After & $\begin{array}{l}-0.0616^{* * * *} \\
(0.0228)\end{array}$ & $\begin{array}{c}-0.0624^{* * * *} \\
(0.0224)\end{array}$ \\
\hline Treatment & $\begin{array}{l}-0.0195 \\
(0.0182)\end{array}$ & $\begin{array}{l}-0.0248 \\
(0.0177)\end{array}$ \\
\hline After & $\begin{array}{c}0.0258 \\
(0.0213)\end{array}$ & $\begin{array}{c}0.0265 \\
(0.0212)\end{array}$ \\
\hline $\operatorname{Ln}(\text { Equity })_{t}$ & $\begin{array}{l}-0.0400^{* * * *} \\
(0.0065)\end{array}$ & $\begin{array}{c}-0.0392^{* * *} \\
(0.0063)\end{array}$ \\
\hline $\operatorname{Ln}(D e b t)_{t}$ & $\begin{array}{l}0.0335^{* * *} \\
(0.0034)\end{array}$ & $\begin{array}{l}0.0299^{* * *} \\
(0.0031)\end{array}$ \\
\hline $1 / \sigma_{E t}$ & $\begin{array}{l}-0.0549^{* * *} \\
(0.0057)\end{array}$ & $\begin{array}{l}-0.0562^{* * *} \\
(0.0059)\end{array}$ \\
\hline Excess Return $_{t}$ & $\begin{array}{l}-0.0392^{* * *} \\
(0.0105)\end{array}$ & $\begin{array}{l}-0.0409^{* * * *} \\
(0.0113)\end{array}$ \\
\hline Income/Assets $_{t}$ & $\begin{array}{l}-0.0456 \\
(0.1015)\end{array}$ & $\begin{array}{l}-0.0366 \\
(0.1007)\end{array}$ \\
\hline$\Delta$ Tobin's $q^{*}$ After & $\begin{array}{l}-0.0018 \\
(0.0062)\end{array}$ & $\begin{array}{l}-0.0038 \\
(0.0063)\end{array}$ \\
\hline Intercept & $\begin{array}{c}0.3328^{* * *} \\
(0.0416)\end{array}$ & $\begin{array}{l}0.3462^{* * *} \\
(0.0400)\end{array}$ \\
\hline Industry fixed effects & No & Yes \\
\hline $\begin{array}{l}\text { Number of observations } \\
\text { Adjusted } R^{2}\end{array}$ & $\begin{array}{l}2,800 \\
0.2201\end{array}$ & $\begin{array}{l}2,800 \\
0.2120\end{array}$ \\
\hline
\end{tabular}




\section{Table 6}

Difference-in-differences regressions of default risk on liquidity, by expected default frequency (EDF) quartiles.

This table reports the results for the difference-in-differences regressions of the four groups formed according to the size of the $E D F$ in 2000 (pre-decimalization year). This test is based on the matched sample constructed in Table 5. Column 1 consists of firms with the highest EDF in 2000. Column 4 has firms with the lowest $E D F$ in 2000. Treatment is a dummy variable equal to one if a stock is in the treatment group and zero if in the control group. After is a dummy variable equal to one for 2002 (postdecimalization year) and zero for 2000. Treatment*After is the interaction between these two variables. Standard errors are clustered by firm and are shown in parentheses. * ${ }^{* *}$, and ${ }^{* * *}$ indicate statistical significance at the $10 \%, 5 \%$, and $1 \%$ level, respectively.

\begin{tabular}{|c|c|c|c|c|}
\hline Variable & $\begin{array}{l}\text { Highest } E D F_{t} \\
\text { (1) }\end{array}$ & $\begin{array}{l}\text { Second } E D F_{t} \\
\text { (2) }\end{array}$ & $\begin{array}{l}\text { Third } E D F_{t} \\
\text { (3) }\end{array}$ & $\begin{array}{c}\text { Lowest } E D F_{t} \\
\text { (4) }\end{array}$ \\
\hline Treatment ${ }^{*}$ After & $\begin{array}{l}-0.1464^{* *} \\
(0.0660)\end{array}$ & $\begin{array}{c}-0.0976^{* * *} \\
(0.0263)\end{array}$ & $\begin{array}{l}-0.0539^{* * * *} \\
(0.0190)\end{array}$ & $\begin{array}{l}-0.0345^{* *} \\
(0.0152)\end{array}$ \\
\hline Treatment & $\begin{array}{l}-0.0127 \\
(0.0426)\end{array}$ & $\begin{array}{l}-0.0031 \\
(0.0107)\end{array}$ & $\begin{array}{l}-0.0065 \\
(0.0050)\end{array}$ & $\begin{array}{l}0.0000 \\
(0.0030)\end{array}$ \\
\hline After & $\begin{array}{l}-0.1002 \\
(0.0629)\end{array}$ & $\begin{array}{l}0.1297^{* * *} \\
(0.0277)\end{array}$ & $\begin{array}{l}0.0838^{* * *} \\
(0.0241)\end{array}$ & $\begin{array}{c}0.035^{* * * *} \\
(0.0133)\end{array}$ \\
\hline $\operatorname{Ln}(\text { Equity })_{t}$ & $\begin{array}{l}-0.0651^{* * *} \\
(0.0189)\end{array}$ & $\begin{array}{l}-0.0106 \\
(0.0080)\end{array}$ & $\begin{array}{c}-0.0135^{* *} \\
(0.0061)\end{array}$ & $\begin{array}{l}-0.0012 \\
(0.0030)\end{array}$ \\
\hline $\operatorname{Ln}(\text { Debt })_{t}$ & $\begin{array}{l}0.0410^{* * * *} \\
(0.0109)\end{array}$ & $\begin{array}{l}0.0124^{* *} \\
(0.0050)\end{array}$ & $\begin{array}{l}0.0097^{* *} \\
(0.0049)\end{array}$ & $\begin{array}{c}0.0016 \\
(0.0020)\end{array}$ \\
\hline $1 / \sigma_{E t}$ & $\begin{array}{c}-0.1065^{* * *} \\
(0.0219)\end{array}$ & $\begin{array}{c}-0.0385^{* * *} \\
(0.0077)\end{array}$ & $\begin{array}{c}-0.0266^{* * *} \\
(0.0071)\end{array}$ & $\begin{array}{c}-0.0082^{* *} \\
(0.0035)\end{array}$ \\
\hline Excess Return $_{t}$ & $\begin{array}{l}-0.0619^{* *} \\
(0.0261)\end{array}$ & $\begin{array}{l}-0.0141 \\
(0.0112)\end{array}$ & $\begin{array}{l}-0.0043 \\
(0.0085)\end{array}$ & $\begin{array}{l}-0.0013 \\
(0.0035)\end{array}$ \\
\hline Income/Assets $t_{t}$ & $\begin{array}{c}0.0193 \\
(0.2986)\end{array}$ & $\begin{array}{l}-0.0158 \\
(0.1277)\end{array}$ & $\begin{array}{c}-0.1161 \\
(0.1042)\end{array}$ & $\begin{array}{l}-0.1992^{* *} \\
(0.0839)\end{array}$ \\
\hline$\Delta$ Tobin's $q^{*} A f t e r$ & $\begin{array}{c}-0.0307^{* * *} \\
(0.0147)\end{array}$ & $\begin{array}{l}-0.0265 \\
(0.0236)\end{array}$ & $\begin{array}{c}0.0063 \\
(0.0061)\end{array}$ & $\begin{array}{l}-0.0089 \\
(0.0080)\end{array}$ \\
\hline Intercept & $\begin{array}{c}0.7208^{* * *} \\
(0.0772)\end{array}$ & $\begin{array}{l}0.0961^{* *} \\
(0.0381)\end{array}$ & $\begin{array}{l}0.1034^{* * * *} \\
(0.0304)\end{array}$ & $\begin{array}{c}0.0221 \\
(0.0172)\end{array}$ \\
\hline Industry fixed effects & Yes & Yes & Yes & Yes \\
\hline $\begin{array}{l}\text { Number of observations } \\
\text { Adjusted } R^{2}\end{array}$ & $\begin{array}{c}700 \\
0.2928\end{array}$ & $\begin{array}{c}696 \\
0.2243\end{array}$ & $\begin{array}{c}706 \\
0.1660\end{array}$ & $\begin{array}{c}698 \\
0.1137\end{array}$ \\
\hline
\end{tabular}


Table 7

Analysis of the firm value effect.

This table reports the results of subsample analysis based on each expected default frequency (EDF) component. This test is based on the matched sample constructed in Table 5. Column 1 includes only the matched sample of stocks with zero or negative change of $\operatorname{Ln}$ (Equity). In Column 2 the sample includes only firms with positive change of $\operatorname{Ln}$ (Equity). Column 3 evaluates stock with zero or positive change of $L n(D e b t)$, Column 4 includes firms with negative change of $L n(D e b t)$. Treatment is a dummy variable equal to one if a stock is in the treatment group and zero if in the control group. After is a dummy variable equal to one for 2002 (post-decimalization year) and zero for 2000. Treatment*After is the interaction term between these two variables. $Z$-statistics are used to assess the significance of the difference between the coefficients on Treatment*After in the two subsamples. Standard errors are clustered at the firm level and are shown in parentheses. ${ }^{*}, * *$, and ${ }^{* * *}$ indicate statistical significance at the $10 \%, 5 \%$, and $1 \%$ level, respectively.

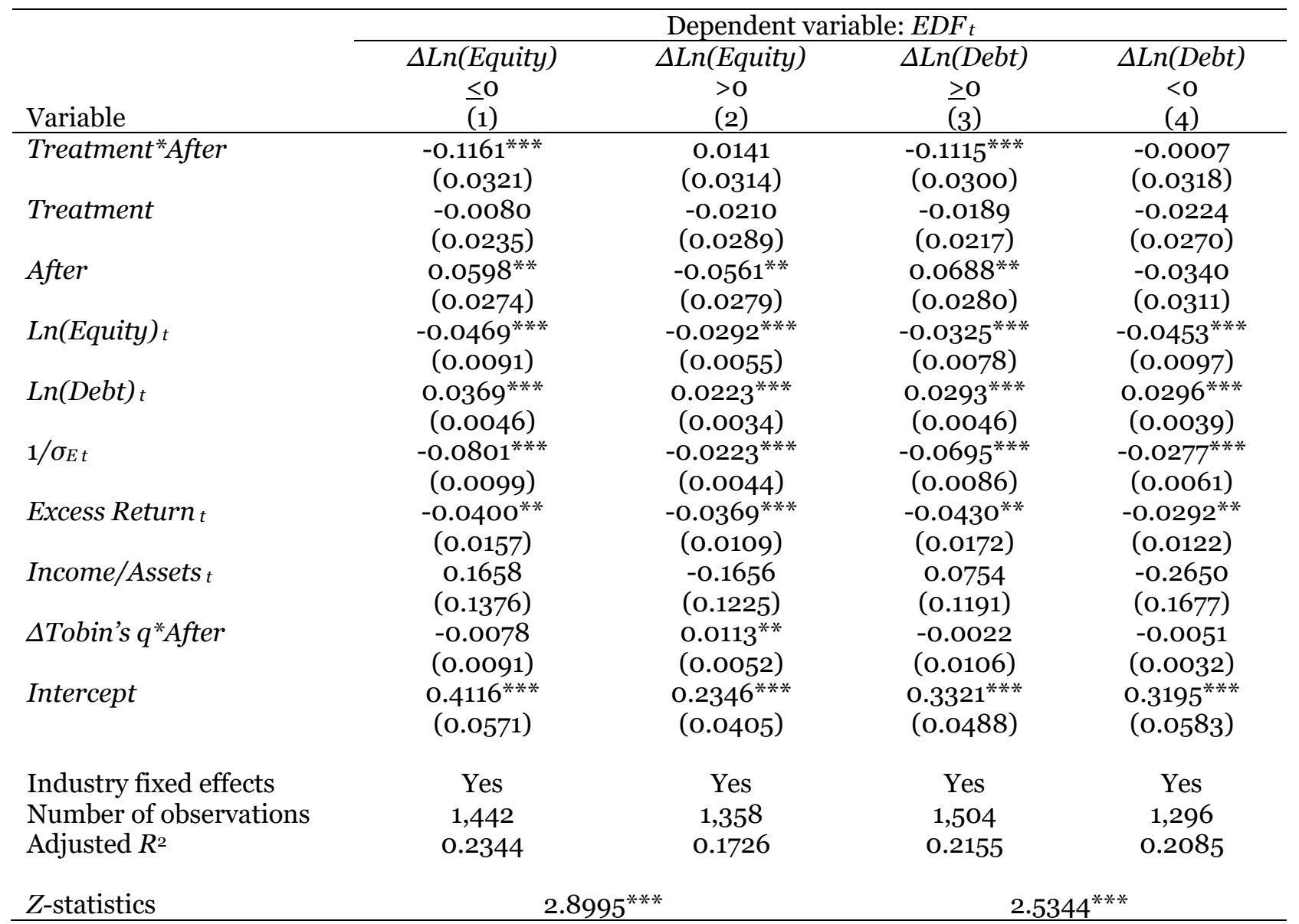


Table 8

Informational efficiency mechanism.

Panel A presents a difference-in-differences test on how changes in Effective Spread surrounding the decimalization year affect the informational efficiency of stock price. Correlation is the absolute value of the correlation between contemporaneous weekly stock returns and the one-week lagged weekly stock returns. Price Delay is 1-( $R$-squared of restricted model / $R$-square of nonrestricted model). The difference-in-differences estimators are computed by subtracting the $\Delta$ Correlation ( $\Delta$ Price Delay) of the control firms from those of the treatment firms. The difference-in-differences test is based on the matched sample used in Table 5. Panel B reports ordinary least squares (OLS) regression results with $\triangle E D F$ as the dependent variable based on the matched sample constructed in Table $5 . \Delta$ presents the change of variables from 2000 (prior to decimalization) to 2002 (after decimalization). Robust standard errors are in parentheses. ${ }^{*},{ }^{* *}$, and ${ }^{* * *}$ indicate statistical significance at the $10 \%, 5 \%$, and $1 \%$ level, respectively.

\begin{tabular}{|c|c|c|c|c|c|c|c|}
\hline \multicolumn{8}{|c|}{ Panel A: Difference-in-differences estimator } \\
\hline \multirow[b]{2}{*}{ Variable } & \multicolumn{2}{|c|}{ Treatment } & \multicolumn{2}{|c|}{ Control } & \multirow{2}{*}{$\begin{array}{l}\text { Difference-in- } \\
\text { differences }\end{array}$} & \multirow{2}{*}{$t$-statistic } & \multirow{2}{*}{$p$-value } \\
\hline & Before & After & Before & After & & & \\
\hline Correlation & 0.1377 & 0.1183 & 0.1338 & 0.1436 & -0.0292 & -3.78 & 0.0002 \\
\hline Price Delay & 0.5929 & 0.4217 & 0.5812 & 0.4726 & -0.0625 & -3.15 & 0.0017 \\
\hline
\end{tabular}

Panel B: OLS regression surrounding the decimalization

\begin{tabular}{lcc}
\hline \multirow{2}{*}{ Variable } & \multicolumn{2}{c}{ Dependent variable: $\Delta E D F$} \\
\cline { 2 - 3 }$\Delta$ Correlation & $0.2088^{* * *}$ & $(2)$ \\
$\Delta$ Price Delay & $(0.0555)$ & $0.0838^{* * *}$ \\
$\Delta L n($ Equity $)$ & & $(0.0208)$ \\
& $-0.1011^{* * *}$ & $(0.0179)$ \\
$\Delta L n($ Debt $)$ & $(0.0184)$ & 0.0059 \\
$\Delta\left(1 / \sigma_{E}\right)$ & 0.0065 & $(0.0041)$ \\
& $(0.0043)$ & $-0.0192^{* * *}$ \\
$\Delta$ Excess Return & $-0.0284^{* * *}$ & $(0.0058)$ \\
& $(0.0060)$ & $-0.0263^{* * *}$ \\
$\Delta$ Income/Assets & $-0.0254^{* * *}$ & $(0.0091)$ \\
$\Delta$ Tobin's $q$ & $(0.0092)$ & -0.1364 \\
& -0.1464 & $(0.1469)$ \\
Intercept & $(0.1483)$ & $0.0102^{*}$ \\
& 0.0089 & $(0.0062)$ \\
Number of observations & $(0.0065)$ & 0.0007 \\
Adjusted $R^{2}$ & -0.0066 & $(0.0092)$ \\
\end{tabular}




\section{Table 9}

Corporate governance mechanism.

Panel A presents a difference-in-differences test on how changes in Effective Spread surrounding the decimalization year affect the blockholder ownership and the number of blockholders. Blockholder ownership (Block) is calculated by aggregating institutional blockholders percentage, which is above $5 \%$ of total common shares outstanding at the end of the year. The number of blockholders (NBlock) is the number of block owners who hold at least $5 \%$ of total common shares outstanding at the end of the year. The difference-in-differences test is based on the matched sample used in Table 5. Panel B reports the ordinary least squares (OLS) regression results with $\triangle E D F$ as the dependent variable based on the matched sample constructed in Table 5. $\Delta$ presents the change of variables from 2000 (prior to decimalization) to 2002 (after decimalization). Robust standard errors are in parentheses. *, ***, and ${ }^{* * *}$ indicate statistical significance at the $10 \%, 5 \%$, and $1 \%$ level, respectively. Panels C and D repeat the analysis by replacing Effective Spread with Price Impact (see Table 1 for definitions of Price Impact).

Panel A: Difference-in-difference estimator-Effective Spread

\begin{tabular}{|c|c|c|c|c|c|c|c|}
\hline \multirow[b]{2}{*}{ Variable } & \multicolumn{2}{|c|}{ Treatment } & \multicolumn{2}{|c|}{ Control } & \multirow{2}{*}{$\begin{array}{c}\text { Difference-in- } \\
\text { differences }\end{array}$} & \multirow{2}{*}{$t$-statistic } & \multirow{2}{*}{$p$-value } \\
\hline & Before & After & Before & After & & & \\
\hline Block & 0.1656 & 0.1793 & 0.1603 & 0.1426 & 0.0314 & 4.94 & $<0.0001$ \\
\hline NBlock & 1.8800 & 2.0857 & 1.8000 & 1.6657 & 0.3400 & 4.76 & $<0.0001$ \\
\hline
\end{tabular}

Panel B: OLS regression surrounding the decimalization-Effective Spread

\begin{tabular}{|c|c|c|}
\hline \multirow[b]{2}{*}{ Variable } & \multicolumn{2}{|c|}{ Dependent variable: $\Delta E D F$} \\
\hline & $(1)$ & (2) \\
\hline$\overline{\Delta B l o c k}$ & $\begin{array}{c}-0.1617^{* * *} \\
(0.0547)\end{array}$ & \\
\hline$\Delta$ NBlock & & $\begin{array}{l}-0.0079^{*} \\
(0.0046)\end{array}$ \\
\hline$\Delta \operatorname{Ln}$ (Equity) & $\begin{array}{c}-0.1080^{* * *} \\
(0.0185)\end{array}$ & $\begin{array}{c}-0.1063^{* * *} \\
(0.0186)\end{array}$ \\
\hline$\Delta \operatorname{Ln}(D e b t)$ & $\begin{array}{c}0.0060 \\
(0.0043)\end{array}$ & $\begin{array}{c}0.0065 \\
(0.0043)\end{array}$ \\
\hline$\Delta\left(1 / \sigma_{E}\right)$ & $\begin{array}{c}-0.0249^{* * *} \\
(0.0057)\end{array}$ & $\begin{array}{c}-0.0251^{* * *} \\
(0.0058)\end{array}$ \\
\hline$\Delta$ Excess Return & $\begin{array}{c}-0.0250^{* * *} \\
(0.0092)\end{array}$ & $\begin{array}{l}-0.0251^{* * *} \\
(0.0092)\end{array}$ \\
\hline AIncome/Assets & $\begin{array}{l}-0.1715 \\
(0.1467)\end{array}$ & $\begin{array}{l}-0.1570 \\
(0.1461)\end{array}$ \\
\hline$\Delta$ Tobin's $q$ & $\begin{array}{c}0.0095 \\
(0.0063)\end{array}$ & $\begin{array}{c}0.0100 \\
(0.0064)\end{array}$ \\
\hline Intercept & $\begin{array}{l}-0.0087 \\
(0.0087)\end{array}$ & $\begin{array}{l}-0.0080 \\
(0.0088)\end{array}$ \\
\hline $\begin{array}{l}\text { Number of observations } \\
\text { Adjusted } R^{2}\end{array}$ & $\begin{array}{c}1,400 \\
0.0760\end{array}$ & $\begin{array}{c}1,400 \\
0.0725\end{array}$ \\
\hline
\end{tabular}


Table 9 Continued

Panel C: Difference-in-difference estimator-Price Impact

\begin{tabular}{|c|c|c|c|c|c|c|c|}
\hline \multirow[b]{2}{*}{ Variable } & \multicolumn{2}{|c|}{ Treatment } & \multicolumn{2}{|c|}{ Control } & \multirow{2}{*}{$\begin{array}{c}\text { Difference-in- } \\
\text { differences }\end{array}$} & \multirow{2}{*}{$t$-statistic } & \multirow{2}{*}{$p$-value } \\
\hline & Before & After & Before & After & & & \\
\hline Block & 0.1679 & 0.1787 & 0.1752 & 0.1754 & 0.0107 & 1.67 & 0.0963 \\
\hline NBlock & 1.9218 & 2.0936 & 2.0184 & 2.0291 & 0.1610 & 2.11 & 0.0351 \\
\hline
\end{tabular}

Panel D: OLS regression surrounding the decimalization-Price Impact

\begin{tabular}{lcc}
\hline \multirow{2}{*}{ Variable } & \multicolumn{2}{c}{ Dependent variable: $\Delta E D F$} \\
\cline { 2 - 3 } & $(1)$ & $(2)$ \\
$\Delta$ Block & $-0.2303^{* * *}$ & $-0.0171^{* * *}$ \\
$\Delta$ Bnlock & $(0.0629)$ & $(0.0049)$ \\
& & $-0.1104^{* * *}$ \\
$\Delta L n($ Debt $)$ & $-0.1129^{* * *}$ & $(0.0171)$ \\
& $(0.0173)$ & $0.0073^{*}$ \\
$\Delta\left(1 / \sigma_{E}\right)$ & $0.0071^{*}$ & $(0.0040)$ \\
& $(0.0040)$ & $-0.0245^{* * *}$ \\
$\Delta$ Excess Return & $-0.0246^{* * *}$ & $(0.0056)$ \\
$\Delta$ Income/Assets & $(0.0056)$ & $-0.0443^{* * *}$ \\
& $-0.0443^{* * *}$ & $(0.0088)$ \\
$\Delta$ Tobin's $q$ & $(0.0088)$ & -0.1571 \\
& -0.1525 & $(0.1137)$ \\
Intercept & $(0.1143)$ & $0.0174^{* *}$ \\
& $0.0174^{* * *}$ & $(0.0068)$ \\
Number of observations & $(0.0068)$ & $0.0164^{*}$ \\
Adjusted $R^{2}$ & $0.0162^{*}$ & $(0.0089)$ \\
\hline
\end{tabular}




\section{Table 10}

Relative importance of mechanisms.

This table reports the ordinary least squares (OLS) regressions results with $\triangle E D F S T D$ as the dependent variable based on the matched sample constructed in Table 5. $\Delta$ presents the change of variables from 2000 (prior to decimalization) to 2002 (after decimalization). $\triangle E D F$ is standardized by subtracting its mean value and dividing the difference by the standard deviation of $\triangle E D F$. Similarly, all the independent variables are standardized. Robust standard errors are in parentheses. .* ${ }^{* *}$, and ${ }^{* * *}$ indicate statistical significance at the $10 \%, 5 \%$, and $1 \%$ level, respectively.

\begin{tabular}{|c|c|c|c|c|}
\hline \multirow[b]{2}{*}{ Variable } & \multicolumn{4}{|c|}{ Dependent variable: $\triangle E D F S T D$} \\
\hline & (1) & (2) & (3) & (4) \\
\hline$\triangle$ Correlation STD & $\begin{array}{l}0.1054^{* * *} \\
(0.0291)\end{array}$ & $\begin{array}{l}0.1084^{* * *} \\
(0.0295)\end{array}$ & & \\
\hline$\triangle$ Price Delay $S T D$ & & & $\begin{array}{l}0.1220^{* * *} \\
(0.0298)\end{array}$ & $\begin{array}{c}0.1208^{* * *} \\
(0.0298)\end{array}$ \\
\hline$\triangle B l o c k$ STD & $\begin{array}{l}-0.0626^{* * *} \\
(0.0238)\end{array}$ & & $\begin{array}{l}-0.0757^{* * *} \\
(0.0244)\end{array}$ & \\
\hline$\triangle N B$ lock STD & & $\begin{array}{l}-0.0307 \\
(0.0235)\end{array}$ & & $\begin{array}{l}-0.0430^{*} \\
(0.0232)\end{array}$ \\
\hline$\Delta \operatorname{Ln}$ (Equity) STD & $\begin{array}{l}-0.2260^{* * *} \\
(0.0402)\end{array}$ & $\begin{array}{c}-0.2223^{* * *} \\
(0.0403)\end{array}$ & $\begin{array}{c}-0.2205^{* * *} \\
(0.0389)\end{array}$ & $\begin{array}{c}-0.2168^{* * * *} \\
(0.0390)\end{array}$ \\
\hline$\Delta L n(D e b t) S T D$ & $\begin{array}{c}0.0214 \\
(0.0166)\end{array}$ & $\begin{array}{c}0.0232 \\
(0.0167)\end{array}$ & $\begin{array}{c}0.0183 \\
(0.0158)\end{array}$ & $\begin{array}{c}0.0203 \\
(0.0158)\end{array}$ \\
\hline$\Delta\left(1 / \sigma_{E}\right) S T D$ & $\begin{array}{l}-0.1166^{* * * *} \\
(0.0248)\end{array}$ & $\begin{array}{l}-0.1175^{* * *} \\
(0.0248)\end{array}$ & $\begin{array}{c}-0.0797^{* * *} \\
(0.0240)\end{array}$ & $\begin{array}{c}-0.0809^{* * *} \\
(0.0240)\end{array}$ \\
\hline$\triangle$ Excess Return $S T D$ & $\begin{array}{l}-0.0919^{* * *} \\
(0.0329)\end{array}$ & $\begin{array}{l}-0.0921^{* * *} \\
(0.0330)\end{array}$ & $\begin{array}{l}-0.0952^{* * *} \\
(0.0327)\end{array}$ & $\begin{array}{c}-0.0955^{* * *} \\
(0.0328)\end{array}$ \\
\hline$\Delta$ Income/Assets STD & $\begin{array}{l}-0.0307 \\
(0.0256)\end{array}$ & $\begin{array}{l}-0.0282 \\
(0.0255)\end{array}$ & $\begin{array}{l}-0.0302 \\
(0.0252)\end{array}$ & $\begin{array}{l}-0.0276 \\
(0.0251)\end{array}$ \\
\hline$\Delta$ Tobin's $q S T D$ & $\begin{array}{c}0.0417 \\
(0.0326)\end{array}$ & $\begin{array}{c}0.0437 \\
(0.0328)\end{array}$ & $\begin{array}{c}0.0474 \\
(0.0311)\end{array}$ & $\begin{array}{c}0.0499 \\
(0.0314)\end{array}$ \\
\hline Intercept & $\begin{array}{c}0.0000 \\
(0.0255)\end{array}$ & $\begin{array}{c}0.0000 \\
(0.0256)\end{array}$ & $\begin{array}{c}0.0000 \\
(0.0255)\end{array}$ & $\begin{array}{c}0.0000 \\
(0.0256)\end{array}$ \\
\hline $\begin{array}{l}\text { Number of observations } \\
\text { Adjusted } R^{2}\end{array}$ & $\begin{array}{c}1,400 \\
0.0862\end{array}$ & $\begin{array}{c}1,400 \\
0.0833\end{array}$ & $\begin{array}{c}1,400 \\
0.0895\end{array}$ & $\begin{array}{c}1,400 \\
0.0858\end{array}$ \\
\hline
\end{tabular}

